\title{
WAGES AND THE ALLOCATION \\ OF HOURS AND EFFORT
}

\author{
Mark Bils \\ Yongsung Chang
}

Working Paper 7309

http://www.nber.org/papers/w7309

\section{NATIONAL BUREAU OF ECONOMIC RESEARCH 1050 Massachusetts Avenue \\ Cambridge, MA 02138 \\ August 1999}

We thank Jang-Ok Cho, Pete Klenow, and participants at several workshops for helpful comments. The views expressed herein are those of the authors and not necessarily those of the National Bureau of Economic Research.

(1) 1999 by Mark Bils and Yongsung Chang. All rights reserved. Short sections of text, not to exceed two paragraphs, may be quoted without explicit permission provided that full credit, including $\odot$ notice, is given to the source. 
Wages and the Allocation of Hours and Effort

Mark Bils and Yongsung Chang

NBER Working Paper No. 7309

August 1999

JEL No. E3

\section{$\underline{\text { ABSTRACT }}$}

We examine the impact of wage stickiness when employment has an effort as well as hours dimension. Despite wages being predetermined, the labor market clears through the effort margin. We compare this model quantitatively to models with flexible and sticky wages, but no effort margin. Allowing for responses in effort dramatically improves the ability of a sticky-wage model to mimic U.S. business cycles. The model produces fluctuations in hours that are intermediate to the standard flexible-wage and sticky-wage models; but output and consumption behave much like in the flexible-wage economy. Consequently, welfare costs of wage stickiness are potentially much, much smaller if one entertains an effort dimension.

Mark Bils

Department of Economics University of Rochester

Rochester, NY 14627 and NBER

bils@troi.cc.rochester.edu
Yongsung Chang

Department of Economics

University of Pennsylvania

McNeil 457, 3178 Locust Walk

Philadelphia PA 19104 


\section{Introduction}

There is an immense literature on the impact of nominal wage rigidities. This literature is partly motivated by the large numbers of workers whose wage rates are updated to reflect economic news, including inflation, only at intervals of a year or longer. According to many writers, these wage rigidities fundamentally alter the short-run response of the economy to shocks, particularly nominal shocks. For instance, an unexpectedly low price level is understood to drive up the real wage, causing firms to cut back on labor until this reduction is sufficient to drive the marginal product of labor up to the level of the "too high" real wage.

One criticism leveled at sticky-wage models is that they suggest that expansions in output will exhibit declines in labor productivity. Yet many cyclical fluctuations exhibit procyclical labor productivity. A common explanation for procyclical productivity is that cyclical movements in labor input are mismeasured. For instance, from N. Gregory Mankiw's text Macroeconomics (1994, page 382).

"If firms do hoard labor, then labor input is overestimated in recessions, because the hoarded workers are probably not working as hard as usual."

We argue, however, that choices for effort, in the face of sticky wages, will not work this way. If intensity of effort reflects a choice of workers or firms then it no longer makes sense to speak of workers as being pushed off their labor supply curves-a central element of the sticky-wage story. Figure 1 illustrates. Suppose that a nominal shock, given a sticky nominal wage, drives the real wage above its flexible-wage counterpart. The conventional interpretation of the impact of sticky wages has the market move from point $E$ to $E^{\prime}$, with labor supply exceeding labor demand. But it is clearly more profitable for a firm to ask more of its workers. As firms ask more of workers this shifts the demand for hours of labor upward. It also shifts the labor supply curve upward reflecting the greater cost to workers of each hour at the higher effort. This continues until work intensity justifies the "too high" real wage at a point like $E$ ". Given the upward shift in labor demand, hours are reduced by less than at $E^{\prime}$. 
The next section formalizes this story of sticky-wages with endogenous effort within a general equilibrium. Under flexible wages individuals make choices on how hard to labor at work, as well as how many hours to work. Greater exertion at work results in a higher wage, but less energy to devote to consumption and leisure activities. ${ }^{1}$ Under sticky wages this choice is restricted. Workers must produce enough to merit the specified wage in order to maintain employment.

Section 3 quantifies the model for empirical purposes. A key issue is the willingness of workers to trade off exertion and hours in production. We calibrate this willingness based primarily on World War II evidence on how piece-rate workers responded in work efficiency to large swings in their weekly hours of work.

Section 4 examines model responses for hours, output, productivity, and a variety of other variables to a nominal and a set of real shocks. We compare responses for our model to those for a model with complete wage flexibility and a model with sticky wages and no endogenous effort response. For all shocks considered, the following is true for our model. Real wages respond as in the typical sticky wage setting; the response in hours worked is very much intermediate to the responses in the standard flexible-wage and sticky-wage models; finally, output and consumption respond very much as in the flexiblewage economy.

We find that allowing for a response in effort dramatically improves the ability of a sticky-wage model to mimic U.S. business cycles. In particular, fluctuations in hours are much more persistent and the correlation between fluctuations in hours and labor productivity is much closer to that observed in the data. Comparisons with the flexiblewage model are less clear. The flexible-wage model better matches observed persistence in productivity. But the model with sticky wages and an effort response is much more successful in generating movements in productivity that lead movements in hours worked.

\footnotetext{
${ }^{1}$ Our treatment of effort choice under flexible wages parallels that of Becker (1985). Becker considers differences in intensity of work as an explanation for differences in individuals' wages, particularly between men and women. Relatedly, Oi (1990) depicts the firm-size effect on wage rates as arising partly from a higher effort choice in larger firms. Hartley (1992) shows how a minimum wage might lead to greater effort, mitigating the legislation's impact on employment.
} 
For U.S. data, fluctuations in real wages, labor productivity, and TFP all dramatically lead those in hours.

We also examine the welfare cost of sticky wages in the face of monetary shocks.

We calibrate that this cost is smaller by nearly a factor of 100 for our model compared to a standard sticky-wage model without effort choice. It is an open question as to why explicit wage contracts do not provide more contingencies for inflation and employment outcomes. Our model provides a partial rational in that, with an effort margin, the benefits of greater wage flexibility are very small.

\section{Model}

\section{Consumers:}

There are a large number of identical infinitely lived consumers in the economy. At time $t$, the representative consumer maximizes expected discounted utility defined over a stream of effective consumption, $x_{\tau}$.

$$
U(t)=E_{t} \sum_{\tau=t}^{\infty} \beta^{\tau-t} u\left(x_{\tau}\right), \beta<1,
$$

$E_{t}$ is the expectations operator; the discount factor is $\beta$. Following Becker (1965), consumption activity requires an input of time as well as goods. More exactly, effective consumption reflects commodities $c_{t}$, real balances $m_{t} / P_{t}$ and effective labor spent on consumption activities $\tilde{l}_{t}$. We assume the utility function reflects the following relations.

$$
\begin{aligned}
& u\left(x_{t}\right)=\log x_{t} \\
& x_{t}=z_{t}^{\theta_{t}} \widetilde{l}_{t}^{1-\theta_{t}} \\
& z_{t}=\left[\chi c_{t}^{1-\frac{1}{v}}+(1-\chi)\left(\frac{m_{t}}{P_{t}}\right)^{1-\frac{1}{v}}\right]^{\frac{v}{v-1}}
\end{aligned}
$$


Shifts in preferences are allowed through variations in $\theta_{t}$. An increase in $\theta_{t}$ represents an increase in importance of purchased inputs relative to time in producing effective consumption.

Goods and real money balances combine through a CES function with substitution elasticity $u$. This yields a demand for real balances with elasticity of 1 with respect to consumption and $-\mathrm{v}$ with respect to the nominal interest rate. We can conveniently draw upon a large empirical literature in calibrating a value for $u$.

The distinguishing feature of our model is that the effective amount of labor supplied to the market and to home consumption depends not only on how hours are split between market and home, but also on levels of exertion or effort. Suppose the consumer spends an amount of time $n_{t}$ in the market and $1-n_{t}$ at home for consuming. Let $\phi_{t}$ and $\widetilde{\phi}_{t}$ represent the effort levels he exerts at work and in the activity of consuming. Then we treat effective labor in the market $l_{t}$ and effective time in consumption $\tilde{l}_{t}$ as

$$
\begin{aligned}
& l_{t}=n_{t} \phi_{t}^{\gamma} \\
& \widetilde{l}_{t}=\left(1-n_{t}\right) \widetilde{\phi}_{t}^{\lambda},
\end{aligned}
$$

where both $\gamma$ and $\lambda$ are $\geq 0$ and $<1$.

We impose a constraint on the available energy that a consumer can exert in market and non-market activity. The "energy constraint" is

(1) $\quad \phi_{t} n_{t}+\left(1-n_{t}\right) \widetilde{\phi}_{t}=1$

This presents consumers with a tradeoff. If the consumer works more intensely in the market, he is left with less energy for non-market activities. (Becker, 1985, introduces such a constraint.) More generally, we can envision a number of ways in which consumers can potentially show themselves to be more desirable employees. For instance workers could reduce absenteeism at the cost of less flexibility to stay at home on days they deem 
that as attractive. Or workers could cut back on consumption activities that make them less productive and attractive as employees, such as carousing to late hours during the workweek.

The consumer spends his money income for purchases of consumption goods $c_{t}$, investment $i_{t}$, and money holdings $m_{t}$. Income includes labor income, rental income and a cash transfer from the government. Given the nominal wage rate $W_{t}$, rental rate $R_{t}$, price of goods $P_{t}$, and money transfer from government $T_{t}$, the budget constraints are

$$
c_{t}+\frac{m_{t}}{P_{t}}+i_{t} \leq \frac{W_{t}}{P_{t}} n_{t}+\frac{R_{t}}{P_{t}} k_{t}+\frac{m_{t-1}}{P_{t}}+\frac{T_{t}}{P_{t}}
$$

$$
k_{t+1}=i_{t}+(1-\delta) k_{t}
$$

The money transfer from the government reflects the income from money creation. $T_{t}=M_{t}-M_{t-1}=\left(\mu_{t}-1\right) M_{t-1}$, where $\mu_{t}=\frac{M_{t}}{M_{t-1}}$. Capital depreciates at rate $\delta$.

The effective labor of a worker is $n_{t} \phi_{t}^{\gamma}$. The wage is related to hourly effort $\phi_{t}$ by

$$
\frac{W_{t}}{P_{t}}=\Omega_{t} \phi_{t}^{\gamma}
$$

$\Omega_{t}$ is the market's valuation of labor, determined in general equilibrium as described below. Equation (4) has two separate interpretations depending on whether wages are flexible or sticky. Under flexible wages it represents the ability of a worker to earn a higher wage by exerting greater effort. An individual worker treats the marginal value of labor, $\Omega_{t}$, as given with respect to his actions. Therefore, he views each 1 percent expansion in effort $\phi_{t}$ to result in a $\gamma$ percent real wage increase. Under sticky wages the worker takes not only $\Omega_{\mathrm{t}}$ but also the real wage as given. Therefore, to be employed, the worker has to provide an effort dictated by 
$\left(4^{\prime}\right)$

$$
\phi_{t}=\left(\frac{W_{t}}{P_{t}} / \Omega_{t}\right)^{1 / \gamma}
$$

Under flexible wages, consumer maximization yields two static first-order conditions for choosing effort and hours worked and two dynamic first-order conditions for choosing investment in capital and investment in real money balances.

$$
\phi_{i} ; \frac{\lambda \phi_{t}}{1-n_{t} \phi_{t}}=\frac{\gamma \theta_{t}}{1-\theta_{t}} \frac{W_{t}}{P_{t} \widetilde{c}_{t}}
$$

(6) $\quad n_{t} ; \quad \frac{1-\lambda}{1-n_{t}}+\frac{\lambda \phi_{t}}{1-n_{t} \phi_{t}}=\frac{\theta_{t}}{1-\theta_{t}} \frac{W_{t}}{P_{t} \widetilde{c}_{t}}$

(7) $\quad k_{t+1} ; \quad \beta \frac{\widetilde{c}_{t}}{\theta_{t}} E_{t}\left[\frac{R_{t+1} / P_{t+1}+1-\delta}{\widetilde{c}_{t+1} / \theta_{t+1}}\right]=1$

(8) $\quad m_{t} ; \quad \frac{1-\chi}{\chi}\left(\frac{m_{t}}{P_{t} \widetilde{c}_{t}}\right)^{-\frac{1}{v}}=1-\beta E_{t}\left[\frac{\theta_{t+1} P_{t} \widetilde{c}_{t}}{\theta_{t} P_{t+1} \widetilde{c}_{t+1}}\right]$

where $\widetilde{c}_{t}=c_{t}\left[1+\frac{1-\chi}{\chi}\left(\frac{m_{t}}{P_{t} c_{t}}\right)^{1-\frac{1}{v}}\right]$ is consumption magnified by a factor equal to one plus the foregone interest cost of real balances held per unit of consumption.

With flexible wages equations (1), (5), and (6) yield the relative time devoted to market work and the relative rates of exertion in market and home activity.

$$
\begin{aligned}
& \frac{n_{t}}{1-n_{t}}=\frac{1-\gamma}{1-\lambda} \frac{\theta_{t}}{1-\theta_{t}} \frac{W_{t}}{P_{t} \widetilde{c}_{t}}-1 \\
& \frac{\phi_{t}}{\widetilde{\phi}_{t}}=\frac{\gamma(1-\lambda)}{\lambda(1-\gamma)}
\end{aligned}
$$

Along a steady-state path with common growth in consumption and real wages, as we will have below, hours supplied to the market are constant. Exertion in market work relative 
to at home is constant at all times. If the parameters $\gamma$ and $\lambda$ are equal then $\frac{\phi_{t}}{\widetilde{\phi}_{t}}$ equals one; furthermore, neither $\phi_{t}$ nor $\widetilde{\phi}_{t}$ varies cyclically. If $\gamma>\lambda$, then $\frac{\phi_{t}}{\widetilde{\phi}_{t}}$ is greater than one.

This further implies that both $\phi_{t}$ and $\widetilde{\phi}_{t}$ will vary opposite fluctuations in market hours. If the wage is predetermined then workers are not free ex-post to choose effort. First-order condition (5) becomes irrelevant, with $\phi_{t}$ instead determined by the constraint in $\left(4^{\prime}\right)$. In a typical sticky wage model, if the real wage is too high ex-post, hours are reduced to drive up the marginal product of labor. Here by working harder workers maintain the choice to work longer hours. In fact, even though the wage is sticky the labor market continues to clear. (Recall Figure 1.)

Firms:

There are a large number of identical firms operating under constant returns to scale in capital and effective labor. Firms hire capital and labor each period to maximize profits $\left(P_{t} Y_{t}-W_{t} N_{t}-R_{t} K_{t}\right)$ subject to the production function

$$
Y_{t} \equiv F\left(K_{t}, N_{t}, \Phi_{t} ; A_{t}, Q_{t}\right) \equiv A_{t} K_{t}^{1-\alpha}\left(Q_{t} N_{t} \Phi_{t}^{\gamma}\right)^{\alpha}
$$

$\Phi_{t}$ represents aggregate effort level; $A_{t}$ reflects temporary productivity shifts, whereas $Q_{t}$ reflects a deterministic trend of technology that grows at rate $g$.

The first order conditions for capital and labor are

$$
\frac{R_{t}}{P_{t}}=M P K_{t}=(1-\alpha) A_{t} K_{t}^{-\alpha}\left(Q_{t} N_{t} \Phi_{t}^{\gamma}\right)^{\alpha}
$$

(11) $\frac{W_{t}}{P_{t}}=M P N_{t}=\alpha A_{t} K_{t}^{1-\alpha} Q_{t}^{\alpha} N_{t}^{\alpha-1} \Phi_{t}^{\gamma \alpha}$. 
The first-order condition for labor yields a wage rate per efficiency unit of labor equal to $\Omega_{t}=\alpha A_{t} Q_{t}^{\alpha}\left(\frac{K_{t}}{N_{t} \Phi_{t}^{\gamma}}\right)^{1-\alpha}$.

The wage rates for workers must be specified a period in advance-this is the source of wage stickiness. The wage is chosen to minimize the expected cost of labor in efficiency units, recognizing that the wage dictates the level of effort that firms can require. The first-order condition for this choice can be written as:

$$
W_{t+1} ; W_{t+1} E_{t}\left[\frac{\theta_{t+1} n_{t+1}}{P_{t+1} \widetilde{c}_{t+1}}\right]=\frac{1-\lambda}{1-\gamma} E_{t}\left[\frac{\left(1-\theta_{t+1}\right) n_{t+1}}{1-n_{t+1}}\right]
$$

\section{Rational Expectations Equilibrium:}

The markets for goods, labor, and money clear each period. A rational expectations equilibrium is a set of stochastic processes for the endogenous variables $\left\{Y_{t}, K_{t}, N_{t}, \phi_{t}, c_{t}, m_{t}, P_{t}, W_{t}, R_{t}\right\}$ that satisfies (3), (4'), (6)-(8), (10)-(12), and market clearing for exogenous processes $\left\{A_{t}, \theta_{t}, \mu_{t}, Q_{t}\right\}$. The model is solved numerically using a log-linear approximation of the system of first order conditions and constraints of the stationary economy around the steady state as in King, Plosser and Rebelo (1988.) ${ }^{2}$

\section{Calibration of Model Parameters and Shocks}

In our model the labor market clears, despite short-run wage stickiness, thanks to fluctuations in market effort. Consequently, the model's predictions for fluctuations in hours and output depend not only on the conventional elasticity of labor supply, but also on how desired hours are affected by these fluctuations in effort. That, in turn, depends on the parameters $\gamma$ and $\lambda$. As an example, in the limit as $\gamma$ and $\lambda$ approach one hours and

\footnotetext{
${ }^{2}$ Given the existence of trends in technology and the inoney supply, we need to transform the economy so that it admits a stationary solution. We can do so by dividing real variables by the technology index and nominal variables by the previous period's money stock. (To save on notation, we use the same variables for the transformed stationary variables.)
} 
effort are perfect substitutes. Consider a nominal shock that drives up the real wage and effort by one percent. Workers' hours simply decrease by one percent, holding output (and welfare) constant. More generally, however, the increase in real wage and effort leads to a lesser decrease in hours, an increase in output, and a fall in effective leisure $\tilde{l}_{t}$.

\section{Calibrating the Elasticity of Labor Supply:}

Let $\xi$ denote the elasticity response of hours to the real wage, holding current consumption expenditures constant. The model implies an elasticity of one for $(1-n)$ with respect to the wage. (See equation (5).) Therefore it implies a value of approximately $\frac{1-n}{n}$ for $\xi$. We set the compensated elasticity of labor supply, $\xi$, equal to one. This value is much lower than what is typically employed in simulations of real business cycles, but is quite large relative to most estimates from cross-sectional and panel data (Ghez and Becker, 1975, MaCurdy, 1981, and Altonji, 1986). ${ }^{3}$

\section{Calibrating $\frac{\phi}{\widetilde{\phi}}$ :}

As discussed above, the optimal ratio of effort in market work relative to that in consumption is $\frac{\phi}{\tilde{\phi}}=\frac{\gamma(1-\lambda)}{\lambda(1-\gamma)}$. Thus knowing $\frac{\phi}{\widetilde{\phi}}$ is sufficient to determine a relationship between the parameters $\lambda$ and $\gamma$. Quantifying $\frac{\phi}{\widetilde{\phi}}$ exactly is not feasible. We start from a presumption that $\frac{\phi}{\widetilde{\phi}}$ is greater than (or equal to) one. Passmore, et. al. (1974), in the World Health Organization publication Handbook on Human Nutritional Requirements, present energy expenditures for work in various occupations as well as for a range of leisure activities. These calculations are shown in Table 1. Results are given separately

\footnotetext{
${ }^{3}$ Several studies have examined how time is divided between market and non-market pursuits based on time use diaries. (Examples include Hill, 1983, Juster and Stafford, 1985, 1991.) From Juster and Stafford (1991), a sample of men in the United States in 1981 report spending 48 hours per week in market work, including commuting, and 42 hours in social entertainment and various sorts of passive and active leisure. For women the comparable number of hours are respectively 26 and 42 . These numbers suggest a value for $\frac{1-n}{n}$ of one or perhaps somewhat larger.
} 
for a $65 \mathrm{~kg}$ man and a $55 \mathrm{~kg}$ woman. All figures are in terms of kilo-calories expended over an 8 hour period. For the $65 \mathrm{~kg}$ man leisure activities exhibit a range per 8 hours of 700 to 1500 kilo-calories, for the $55 \mathrm{~kg}$ woman the range is 580 to 980 kilo-calories. Occupations are classified as light, moderately active, very active, and exceptionally active. The exceptionally active occupations (lumberjacks, blacksmiths, rickshaw pullers) are relatively uncommon in modern rich economies. If we compare moderately active occupations to leisure activities, we see that work is associated with about 30 percent greater energy expenditure than the midpoint of the range for leisure activities. In addition to physical and caloric considerations, most leisure and consumption activities are presumably less tiresome mentally than typical market work. Based on these considerations, we set the ratio $\frac{\phi}{\widetilde{\phi}}$ at $\frac{3}{2}$. (We explore the robustness of the results to this choice.) This implies $\lambda$ is related to $\gamma$ as $\lambda=\frac{2 \gamma}{3-\gamma}$.

\section{Calibrating $\gamma$ from WWII experiences:}

How desired hours respond to exogenous changes in effort reflects parameter $\gamma$. But we do not see a practical way to estimate this response. As a result of World War II, many workers in manufacturing faced dramatic changes in their workweeks. The U.S. Bureau of Labor Statistics (BLS) took advantage of these variations to study the impact of hours of work on efficiency and absenteeism. The results of these studies are reported in Studies of the Effects of Long Working Hours, BLS (1944) and Hours of Work and Output, BLS (1947). By measuring how workers vary effort in response to an enforced change in hours, this provides an alternative way to judge to what extent hours and effort are substitutes.

Productivity, output per hour, equals $\phi_{t}^{\gamma}$. From equation (5) for effort choice, $\frac{\phi_{t} n_{t}}{1-n_{1} \phi_{t}}=\frac{\gamma}{\lambda} \frac{\theta_{1}}{1-\theta_{1}} \frac{W_{t} n_{t}}{P_{t} \widetilde{c}_{t}}$. If consumption expenditures move one-for-one with earnings then $\phi_{t} n_{t}$ is constant. This implies changes in productivity per hour are related to changes in hours according to 


$$
\Delta \ln \left(\frac{y_{t}}{n_{t}}\right)=\gamma \Delta \ln \left(\phi_{t}\right)=-\gamma \Delta \ln \left(n_{t}\right)
$$

Thus the response of productivity to the wartime changes in hours yields a value for $\gamma$.

More generally, the ratio of consumption to earnings will vary with the large changes in hours. Given that wartime changes in hours were transitory and restrictions were placed on consumer purchases during the war, workers probably devoted some of the extra earnings from longer hours to savings. As an extreme, suppose that consumption was not affected by the wartime changes in hours. Substituting equation (4) for the real wage in (5), changes in productivity are, in this case, related to changes in hours by

$$
\Delta \ln \left(\frac{y_{t}}{n_{t}}\right)=\gamma \Delta \ln \left(\phi_{t}\right) \approx-\gamma\left[\frac{n \phi}{1-\gamma(1-n \phi)}\right] \Delta \ln \left(n_{t}\right)=-\left(\frac{3 \gamma}{5-2 \gamma}\right) \Delta \ln \left(n_{t}\right)
$$

where $\approx$ reflects a first-order approximation. The last equality follows from setting $\phi n$ equal to $3 / 5$ to be consistent with the calibrations above. Productivity falls less if consumption does not vary. We first use the war data to observe how much productivity declined in response to an expansion in hours. We then use that response to calibrate two extreme values for $\gamma$ based on consumption varying one-for-one with earnings or being unaffected.

The BLS examined 78 case studies covering 3,105 workers in 34 plants across a variety of industries. Each case included anywhere from 1 to 5 changes in hours. ${ }^{4}$ In order to estimate the response of effort to changes in hours workers must be choosing their level of effort. We are concerned that this may not be true for workers paid at an

\footnotetext{
${ }^{4}$ The BLS visited over 800 plants; but most did not meet the requirements of the study. From Bulletin 917: "In order to permit the effects of various schedules of hours to emerge clearly, it was necessary to rule out all other variables. A plant, therefore, could not be studied if, during the various periods to be surveyed, hours were not maintained consistently at fairly fixed and definite schedules. During these periods, the operations performed by the workers to be studied had to remain essentially unchanged, and the number of identical workers involved had to be reasonably large."
} 
hourly rate. Therefore we restrict our attention to cases involving piece rate workers. ${ }^{5}$

We further restrict attention to cases where the pace of work is described as dictated by the worker, as opposed to by machine. We also required that terms of compensation were essentially unaltered across the changes in hours. We are left with 27 groups of workers and 62 hours changes. ${ }^{6}$

Implicit in this calculation is that productivity is not affected by an increase in hours worked per week except through effort. If an expansion in hours is associated with a decrease in capital per worker this could lower productivity. We do not believe this was the case for these workers. Adding work on Saturdays or Sundays or lengthening a shift should not reduce capital per worker. Furthermore, the study selected groups of workers where the number and mix of workers in the group did not change too significantly.

Many of the large increases in hours are associated with the United States' entry into the war. Conversely, many of the large decreases reflect the end of the war. Entry into war may have provided a strong psychological stimulus to productivity, particularly for workers producing munitions and other goods directly related to the war effort. For the case of 18 workers involved in machining metal parts BLS (1947) states, "It is pertinent to an analysis of the findings in this plant that workers became aware of the demand for company's products in the war effort ... " For this reason, we introduce a control variable, $\Delta W a r$, that equals 1 for periods reflecting entry into the war, equals -1 for periods reflecting the end of the war, and equals 0 otherwise.

Results are presented in Table 2. The first column regresses the reported percent change in efficiency solely on the percent change in hours. (The change in hours is net of any change in absenteeism.) The estimated impact on efficiency, though negative, is fairly small and only marginally significant. The regression in Column 2 controls for $\Delta W a r$. The

\footnotetext{
${ }^{5}$ The study was heavily weighted toward groups paid by piece-rate, as this made it easier to measure workers' output. Bulletin 917 reports that, on average, workers on hourly rates maintained greater efficiency in response to an increase in hours than did those on piece rates.

${ }^{6}$ One case corresponds to 150 workers. All others correspond to a number of workers between 8 and 48 . 11 of these changes occur prior to the war. 16 represent increases in hours from before to after Pearl Harbor. 18 are changes during the war. 16 represent changes from before to after VJ Day. 1 occurred entirely after the war.
} 
war is associated with a very significant positive impact on productivity of 5.6 percent. Productivity now shows an estimated elasticity of -.26 with respect to hours (with a standard error of .07). Lastly, Column 3 interacts $\Delta W$ ar with a zero/one dummy variable, that equals one for the 42 hours changes that are for workers producing goods directly related to the war effort. The impact of the war on productivity is about 8.0 percent for these workers. ${ }^{7}$ The impact of hours on productivity is estimated fairly precisely at an elasticity of -.25 (standard error of .06).

We take the estimated impact on productivity as a .25 percent decrease for each percent increase in hours. If consumption varies one for one with earnings this implies a value for $\gamma$ of .25. If consumption is not varying this implies a value for $\gamma$ of $\frac{5}{14}$.

In the late 1800's and early in this century a number of manufacturing enterprises exhibited dramatic reductions in the workweek. This often occurred in conjunction with adopting three-shift operation in place of two shifts. Goldmark (1912) reports the impact these changes had on productivity per hour for several companies where, for various reasons, particularly good records were maintained. In Table 3 we report these results for 3 cases pertaining to piece-rate workers. In each case we believe it is reasonable to assume that the ratio of labor to effective capital was relatively unaffected by the altered production schedule. The two factories that cut the workweek in 1893, the Salford Iron Works in Manchester England and the Engis Chemical Works near Liege, Belgium, both displayed increases in productivity that offset considerably more than half the reduction in hours per week. For the Zeiss Optical Works in Jena, Germany, which reduced daily hours from 9 to 8 in 1900 , productivity increased more than proportionately to the reduction in hours, actually resulting in an increase in production. All three cases support higher values for $\gamma$ that suggested by the WWII experience.

For our benchmark case we choose a value for $\gamma$ equal to $\frac{1}{3}$. This is near the top of the range of values implied by the WWII evidence of 25 to $\frac{5}{14}$. We explore robustness to a wider range of values.

\footnotetext{
${ }^{7}$ Examples of products not directly related to war are dental equipment, tobacco products, candles, and cough drops. The variable $\Delta$ War is not significant for these workers.
} 


\section{Calibrating Money Demand:}

First-order conditions (7) and (8) imply that money demand is proportional to consumption and has an interest rate $\left(i_{t}\right)$ elasticity of $-v$. There is a very large empirical literature estimating $u$. We take $U=0.1$ as a reasonable value given the range of estimates (e.g., Laidler, 1985). We set the parameter $\chi$ equal to .9999. For a value of 0.1 for $v$ and a nominal interest rate of 8 percent this implies a real balance-consumption ratio, $\frac{m_{t}}{P_{1} c_{1}}$, of 0.51. For the United States for 1954 to 1996 the observed ratio for $\frac{m_{t}}{P_{t} c_{t}}$, measuring money by $M 2$, is 0.24 . The small value of $\frac{m_{i}}{P_{t} c_{t}}$ renders the effect of real balances on consumption demand nearly zero.

Table 4 summarizes the parameter values we have discussed in this section. It also lists parameters we have calibrated at values common in the literature, such as labor's share $\alpha$ and the depreciation rate $\delta$.

Estimating the Autocorrelation of Shocks:

We consider three disturbances to the economy: disturbances to technology $A_{t}$, to preferences $\theta_{t}$, and to the rate of money growth $\mu_{t}$. We denote a variable's percentage deviation from its steady-state value by adding a circumflex [e.g. $\left.\hat{A}_{t}=\log \left(A_{t} / A\right)\right]$. We assume that $S_{t}=\left[\hat{A}_{t} \hat{\theta}_{t} \hat{\mu}_{t}\right]$ reflects a stationary stochastic process,

$$
S_{i}^{\prime}=\rho S_{l-1}{ }^{\prime}+\varepsilon_{l}{ }^{\prime}, \rho=\left[\begin{array}{ccc}
\rho_{A} & 0 & 0 \\
0 & \rho_{0} & 0 \\
0 & 0 & \rho_{\mu}
\end{array}\right], \rho_{A}, \rho_{0}, \rho_{\mu}<1, \varepsilon_{t}=\left[\varepsilon_{A t} \varepsilon_{\theta t} \varepsilon_{\mu t}\right]
$$

(15) $\Theta=E \varepsilon_{\imath}{ }^{\prime} \varepsilon_{l}$

We estimate this process three ways to be consistent first with a model with flexible wages and constant effort, then with a model with sticky wages and constant effort, and finally with a model with sticky wages with an effort response. 
With constant effort we can measure shifts in productivity $\hat{A}_{t}$ in a conventional manner using the Solow residual. But more generally the Solow residual reflects variations in effort

$$
\hat{Y}_{t}-(1-\alpha) \hat{K}_{t}-\alpha \hat{N}_{t}=\hat{A}_{t}+\alpha \gamma \hat{\phi}_{t}
$$

With flexible wages $\hat{\phi}_{t}$ is directly related to $\hat{n}_{t}$ through equations (1), (5), and (6). Under sticky wages, similarly, $E_{t-1} \hat{\phi}_{t}$ can be directly related to $E_{t-1} \hat{n}_{t}$ given the wage setting in equation (12). After subtracting $\alpha \gamma E_{t-1}\left[\hat{\phi}_{t}\right]$ from the Solow residual for $t$, we project what remains on lagged and predetermined variables to construct the variable $E_{t-1} \hat{A}_{t}$. (This is described in greater detail in Appendix A.) Then, given that $E_{t-1} \hat{A}_{t}$ has the same autocorrelation as $\hat{A}_{t}$, we use the series for $E_{t-1} \hat{A}_{t}$ to estimate $\rho_{A}$.

If wages are flexible, preference shifts can be related to observed variables using equations (5) and (6) as $\frac{\theta_{t}}{1-\theta_{t}}=\frac{1-\lambda}{1-\gamma} \frac{P_{1} \widetilde{c}_{t}}{W_{t}} \frac{1}{1-n_{t}}$. This parallels Hall (1986), Parkin (1988), and Baxter and King's (1991) use of the static first-order condition to measure preference shocks. If wages are sticky, then this relationship holds in expectation as of $t-1$. As in the treatment of $\hat{A}_{t}$, we first use this relationship to construct $E_{t-1} \hat{\theta}_{t}$, then estimate $\rho_{\theta}$ from its autocorrelation.

Lastly, we need to calibrate the autocorrelation parameter $\rho_{\mu}$ of monetary shocks. Our reading of the literature provides no consensus on an appropriate measure of monetary shocks. Short of such a measure, we proceed as follows to construct a measure of money growth that is consistent with our model. The money demand equation requires that nominal money holdings be proportional to nominal expenditures on consumption and exhibit an elasticity with respect to the nominal interest rate $\left(i_{t}\right)$ of $-v$.

$$
\hat{m}_{t}=\left(\hat{P}_{t}+\hat{c}_{t}\right)-v\left(\frac{\hat{i}_{t}}{1+i_{t}}\right)
$$


Taking first differences and employing a value for $v$ of .1 , this yields a measure of disturbances to the rate of growth in money. A problem with this measure is that, if we are incorrect in assuming elasticities of money demand of 1 and -.1 with respect to nominal consumption and nominal interest rates, then our measure of nominal shocks will be correlated spuriously with spending and interest rates. To mitigate this problem, we instrument for changes in the variable with the federal funds rate, the growth rate of nonborrowed reserves, the ratio of non-borrowed reserves to total reserves, and their one period lagged values. These variables are often used in the literature as measures of monetary policy (e.g., Bernanke and Blinder, 1992, Christiano, Eichenbaum and Evans, 1996, Sims and Zha, 1994, and Strongin, 1995). We will refer to the resulting series as our instrumented monetary shocks.

Estimation of the three shocks, with results, is described in detail in Appendix A.

\section{Results for Cyclical Fluctuations}

\section{The cyclical behavior of hours and productivity}

We contrast three models with respect to their predictions for how output, consumption, investment, productivity, and prices respond to shocks. The models being a standard flexible wage model, a model with sticky nominal wages and rationing in the labor market, and the model we have introduced with sticky nominal wages where the labor market clears through endogenous effort. First, however, we examine the behavior of these variables for the U.S. economy with a particular emphasis on the cyclical behavior of productivity.

Table 5 presents the standard deviations, first-order autocorrelations, and contemporaneous correlations with real GDP for the eight series real GDP, consumption, investment, hours, prices, real wage, labor productivity, and the Solow residual (TFP) for the U.S. economy. The series are annual Hodrick-Prescott filtered data for 1954-1996. Prices and the real wage reflect the GDP deflator. The hours series are from the Bureau of Labor Statistics and reflect a correction for changes in the composition of the 
workforce by age and education. ${ }^{8}$ The series for the real wage, labor productivity, and TFP are corrected in a consistent manner. As has been often documented, variability of hours is nearly as large as that in output, with the standard deviation in the real wage and labor productivity less than half that of hours. Note that fluctuations in hours are actually more persistent than fluctuations in labor productivity or TFP, in contrast to typical results for models that have been calibrated. Prices are very countercyclical for the period 1954 to 1996 , with a correlation of -.57 with output.

Table 6 presents correlations of the real wage, labor productivity, and the Solow residual with hours contemporaneously as well as for leads and lags of up to 3 years. Real wages and TFP exhibit contemporaneously correlations of .43 and .45 with hours, but labor productivity and hours are largely uncorrelated. Fluctuations in all three variables dramatically lead fluctuations in hours. For both labor productivity and TFP the correlation at a lead of 2 years is over 5 .

With sticky wages, but endogenous effort, an unexpected increase in prices reduces the real wage, causing a decrease in effort and TFP. It is well known that price and TFP are strongly negatively correlated in the data. For instance, Figure 2a shows the impulse responses from a bivariate VAR of inflation and TFP for the period 1960-1995. A linear time trend is included. The number of lags included equals 2 (representing 2 years). The VAR is structured with inflation entering first in the ordering. TFP responds to 1 percent increase in inflation by decreasing initially by about .25 percent and by even more in the following year. However, the response of TFP to inflation does not clearly capture the relation between nominal shocks and effort if there are important cyclical shocks to technology. The negative impact of productivity shocks on prices might create a negative association between inflation and TFP even if effort does not vary.

Ideally, we would like to isolate the response of TFP to innovations in inflation due solely to exogenous monetary shocks. Figure $2 \mathrm{~b}$ repeats the VAR presented in Figure 2a, but replacing the rate of inflation with our instrumented monetary shocks. (See

\footnotetext{
${ }^{8}$ The adjustments for labor force composition are described in detail in BLS (1993). Without correcting the standard deviation of hours is 2.19 percent instead of 2.01 percent. Without correcting the correlations of labor productivity with output and hours equal .30 and -.21 , rather than the corresponding values in Table 3 of .48 and .06 .
} 
Section 3.) TFP responds to a 1 percent increase in (instrumented) money growth by decreasing quite dramatically by about 3 to .4 percent in the first two years. ${ }^{9}$

\section{Impulse responses for the models}

We examine impulse responses to technology, preference and monetary shocks for each of the three models. ${ }^{10}$ First consider a technology shock of one percent. The responses of the flexible wage model with constant effort are given in Figure 3a. These responses are standard. Investment responds much more than consumption and output, with consumption's response being humped shape. The real wage (and labor productivity) responds much more, and much more persistently, than hours. ${ }^{11}$

Now consider the response, Figure $3 b$, for a sticky-wage model with no response in effort $(\gamma=0)$. For the first year, during which the nominal wage is predetermined, the impact on the real wage is simply the opposite of the response of the price level. The price level falls by about $2 / 3$ of a percent. The induced increase in the real wage of $2 / 3$ of a percent is somewhat smaller than the real wage increase under flexible wages of about 0.9 percent. Because employment is demand determined, this leads to a somewhat larger increase in employment and output in the first year.

The response of the model with sticky wages but endogenous effort - Figure $3 c-$ is intermediate to the flexible-wage and standard sticky-wage results. The path for the real wage looks much like the simple sticky wage model. The sticky nominal wage causes the real wage to increase by less than its flexible wage counterpart. This leads to a reduction in the productivity of effort $\left(\phi_{t}^{\gamma}\right)$ by $1 / 4$ percent. Hours increase by about 0.6 percent, which is greater than the response of $1 / 3$ percent under flexible wages and smaller than the

\footnotetext{
9 The results in Figure 2a, using inflation and TFP, are qualitatively robust to reordering the variables. For Figure $2 b$, the results still show a negative response in TFP to the monetary shock; but it is smaller and not statistically significant at the $5 \%$ level.

${ }^{10}$ Recall that for each model, the persistence of shocks corresponds to the autocorrelation of the shocks estimated from that model. In practice, the differences in persistence of shocks across models is very similar; so this has little impact on the appearance of the impulse responses.
} 
response of 1 percent under the standard sticky model. Overall, the expansions in output, consumption, and investment look very much like that under completely flexible wages.

Next we examine the responses of these economies to a preference shock reflecting a one-percent increase in $\theta_{t}$. The responses of the flexible wage economy are given in Figure 4a. The preference shock causes both consumption and investment to expand, with the increase in consumption modestly larger. Output expands about $3 / 4$ percent the first year, declining gradually to be about 0.4 percent above trend in the fifth year. Prices and real wages are countercyclical. Prices fall by $1 / 2$ percent in the first year. Real wages fall by about $1 / 3$ percent initially, but only slightly by the fifth year.

The response of the standard sticky-wage model to the preference shock, an increase in consumption demand, is quite perverse. Looking at Figure $4 b$, the increase in consumption drives up the demand for real balances causing prices to drop. This, in turn, increases the real wage by about $1 / 4$ percent in the first year. Because the level of technology and the capital stock are unaffected in the first year, this increase in the real wage necessarily generates a fall in employment and output. So an increase in demand for consumption actually results in a contraction in output in the first year, with the increase in consumption more than offset by a drop in investment. As nominal wages adjust investment and output subsequently increase.

Again the response of the sticky wage model with effort - Figure $4 c-$ is intermediate to the other two models. The real wage rises initially, similarly to the simple sticky wage model. But this induces an increase in productive effort at work that increases the marginal product of labor. This increase in effort exceeds the increase in real wage and results in an expansion in hours. The increase in hours in the first year is substantially less than for the flexible wage model. But thanks to the increase in effort, output expands nearly as much as under flexible wages. Note that hours and output both peak in the second year of the shock, with hours in particular showing a very strong humped shape response. Furthermore, real wages (and labor productivity) and TFP

${ }^{11}$ We also examined a flexible-wage model with endogenous effort. Effort moves very little. Bils and Cho (1994) and Burnside, Eichenbaum, and Rebelo (1993) achieve greater movements in effort under flexible wages by adding adjustment costs for hours. 
clearly lead the expansion in hours and output. By the time hours peak, TFP is back to normal and the real wage and labor productivity are below trend. The response of the model with sticky wages and endogenous effort to a preference shock is the only example of an impulse response, among the three models and three shocks we consider, that generates productivity leading hours. From Table 6 , this is a striking feature of the data.

Lastly we examine responses to a shock of one percent to the monetary growth rate. The impact on the economy with flexible wages is extremely small (no real variable departs as much as .001 percent from its steady-state value), so we skip to the two sticky wage models. Results for the sticky wage model without effort response appear in Figure 5a. The impact on hours and output is very dramatic. The decline in real wages induces a transitory increase in hours of 4 percent and in output of nearly 3 percent. The expansion is almost entirely through investment spending, which increases by about 8 percent. The monetary shock creates a persistent expansion in consumption, but not in output.

With endogenous effort, Figure $5 b$, the impact of the monetary shock is almost neutralized by the decrease in effort brought about by the decrease in the real wage. Hours still expand significantly by about 2 percent, as opposed to 4 percent. But this increase in hours is largely offset by a decline in effort so that the increase of effective labor in the market is very small. The impact on consumption, investment, and output is also small relative to the case of sticky wages with no effort response. The fall in effort created by the 1 percent monetary shock translates into a one-period drop in TFP of a little more than one percent. This is in the direction we find for a VAR estimated on U.S. data, as reported above; but the model's response is several times larger in magnitude.

\section{Cyclical moments for the models}

In Appendix B we present and discuss moments for time series generated from each of the three models in response to shocks to technology, preferences, and monetary growth. (The shocks are quantified as described in Appendix A.) Here we summarize those findings

Allowing for an effort response substantially improves how well a sticky-wage model matches the major features of U.S. business cycles depicted in Tables 5 and 6 . In 
particular, fluctuations in hours become much more persistent (as in the data); and the correlation between fluctuations in hours and labor productivity also becomes much closer to that observed for the data. Comparisons with the flexible-wage model are less clear. The sticky-wage with effort model does much better than the flexible-wage model in producing that productivity strongly leads the cycle, but is somewhat outperformed in a couple of dimensions - persistence of productivity movements and the contemporaneous correlation of hours and labor productivity.

\section{Welfare costs of wage stickiness}

Consumption expenditure and effective leisure behave very similarly for our model with sticky wages and variable effort as they do under flexible wages. This suggests that the welfare consequences of wage stickiness are far lower for our model than in a standard sticky-wage model. We illustrate for the case of nominal shocks to $\mu_{t}$. We set $\rho_{\mu}$ equal to .63 based on the time series for the instrumented monetary shocks. We set the standard deviation of shocks equal to .33 percent. This is roughly consistent with observed price variability for all the models we consider. (See Appendix A.)

Under sticky wages and constant effort, the cost to welfare of the wage rigidity is equivalent to a loss of 0.23 percent of steady-state consumption. (Details on calculating welfare costs are contained in Appendix C.) This is consistent with estimates in Cho, Cooley, and Phaneuf (1997), which range from 05 to 1.2 percent of steady-state output.

For our base model with endogenous effort, with $\gamma=\frac{1}{3}$ and steady-state $\frac{\phi}{\tilde{\phi}}$ equal to $\frac{3}{2}$, the welfare cost of nominal shocks is only 0.0020 percent of steady-state consumption. Thus the cost is reduced by two orders of magnitude. ${ }^{12}$ For annual consumption of $\$ 30,000$ this translates into a cost of only 60 cents per year. It is a long-standing puzzle why wage agreements do not build in more indexing and flexibility. Our model, by allowing an effort response, suggests the cost of wage stickiness may be extremely small.

\footnotetext{
${ }^{12}$ If we do not scale down the monetary disturbances the welfare costs of sticky wages are 6.37 percent of consumption with constant effort, but only 0.06 percent with the effort response.
} 
Thus it may require only very small costs of writing wage flexibility into labor arrangements to rationalize sticky wages in practice.

We examined several other parameterizations of the model with endogenous effort. We first let marginal variations in effort be less productive by setting $\gamma=\frac{1}{10}$, while maintaining $\frac{\phi}{\tilde{\phi}}$ equal to $\frac{3}{2}$ (implying $\lambda=.069$ ). This increases the welfare cost of wage rigidity to .0036 percent of steady-state consumption. The steady-state ratio of $\frac{\phi}{\tilde{\phi}}$ affects the cost of fluctuations in effort. If we make $\frac{\phi}{\tilde{\phi}}$ equal to one, by setting both $\gamma$ and $\lambda$ equal to $\frac{1}{3}$, then sticky wages create essentially a zero welfare cost. ("Effective" time in production and consumption are unaffected by sticky wages to a first-order approximation if $\gamma$ equals $\lambda$.) Conversely, holding $\gamma$ equal to $\frac{1}{3}$, but reducing $\lambda$ to make $\frac{\phi}{\tilde{\phi}}$ equal to 3 increases the welfare cost to .0124 percent of steady-state consumption. But note this remains only about one-twentieth the magnitude of welfare costs in the absence of an effort response.

\section{Conclusions}

We examine the impact of wage stickiness when employment has an effort as well as hours dimension. Despite wages being predetermined, the labor market clears through the effort margin. Sticky wages do create inefficient fluctuations in exertion at work relative to at home. But the consumption-leisure margin is much less distorted than if no response in effort is allowed.

We compare our model quantitatively to two models without an effort margin, one with flexible wages and one with sticky wages. Though movements in real wages for our model behave very much as in the typical sticky wage setting, fluctuations in hours worked are intermediate to the responses in the standard flexible-wage and sticky-wage models. Furthermore, the impact the sticky wage has on hours worked is largely offset by variations in effort at work. As a result, output and consumption behave much like in the 
flexible-wage economy. We find that allowing for variations in effort significantly help a sticky-wage model match the behavior of U.S. business cycles.

Because the impact of monetary shocks on hours is largely offset by opposite movements in effort, welfare costs of wage stickiness appear to be much smaller, by perhaps two orders of magnitude, if one allows an effort dimension. This result may help explain the apparent lack of short-run flexibility in actual wage practices. 


\section{Appendix A: Estimating the Models' Shocks:}

The three disturbances to technology, preferences, and the rate of money growth are described by equations (14) and (15) of the text.

As discussed in the text, with variable effort the Solow residual reflects variations in effort as well as technology $\hat{A}_{i}$,

$$
\hat{Y}_{t}-(1-\alpha) \hat{K}_{t}-\alpha \hat{N}_{t}=\hat{A}_{t}+\alpha \gamma \hat{\phi}_{t} .
$$

Under sticky wages, optimal wage setting in equation (9) yields an implied value for $E_{t} \hat{\phi}_{t+1}$. Intuitively, $W_{t+1}$ is set such that the expectation of $\frac{\phi_{t+1}}{\bar{\phi}_{t+1}}$ reflects its flexible wage counterpart of $\frac{\gamma(1-\lambda)}{\lambda(1-\gamma)}$. For $\gamma \neq \lambda$ this implies small movements in $E_{i} \hat{\phi}_{t+1}$ to satisfy energy constraint (1). We subtract $\alpha \gamma E_{t} \hat{\phi}_{t+1}$ from the Solow residual at time $t+1$ to yield a variable with expectation at time $t$ equal to $E_{t} \hat{A}_{t+1}=\rho_{A} \hat{A}_{t}$. We construct the expectation of the corrected $t+1$ Solow residual based on a projection on variables $\left\{\hat{Y}_{t}, \hat{Y}_{t-1}, \hat{N}_{t}, \hat{N}_{t-1}, \hat{K}_{t+1}, \hat{K}_{t}, \hat{K}_{t-1},\left(\frac{\hat{W}_{t+1}}{W_{t}}\right),\left(\frac{\hat{w}_{t}}{w_{t-1}}\right)\right\}$ to obtain $E_{t} \hat{A}_{t+1}$. We then estimate $\hat{\rho}_{A}$ from the first-order autocorrelation of $E_{t} \hat{A}_{t+1}$, which equals the autocorrelation of $\hat{A}_{t}$. Finally, we divide $E_{t} \hat{A}_{t+1}\left(=\rho_{A} \hat{A}_{t}\right)$ by $\hat{\rho}_{A}$ to obtain our time series for $\hat{A}_{t}$.

Under flexible wages, first order conditions (5) and (6) reveal the preference shifts $\theta_{t}$ as $\frac{\theta_{t}}{1-\theta_{t}}=\frac{1-\lambda}{1-\gamma} \frac{p_{t} \vec{c}_{t}}{W_{t}} \frac{1}{1-n_{t}}$. Under sticky-wages condition (5) for effort choice is irrelevant. However, given the choice for $W_{t+1}$ in equation (9), the relationship holds as of $t+1$ up to an expectation error as $\frac{\theta_{t+1}}{1-\theta_{t+1}}=\frac{1-\lambda}{1-\gamma} \frac{P_{t+1} \tilde{c}_{t+1}}{W_{t+1}} \frac{1}{1-n_{t+1}} e^{s_{t+1}}$, where $E_{t}\left[e^{s_{t+1}}\right]=1$. Taking expectations of a log-linear approximation yields

$$
E_{t} \hat{\theta}_{t+1}=(1-\theta) E_{t}\left[\frac{n}{1-n} \hat{n}_{t+1}+\hat{\tilde{c}}_{t+1}-\left(\frac{\hat{W}}{P}\right)_{t+1}\right] .
$$

Note $E_{t}\left[\hat{\theta}_{t+1}\right]$ has the same autocorrelation as $\hat{\theta}_{t}=\rho_{\theta}^{-1} E_{t}\left[\hat{\theta}_{t+1}\right]$. We use predicted values from regressing $\hat{\theta}_{t+1}$ on $\left\{\hat{n}_{t}, \hat{n}_{t-1}, \hat{\widetilde{c}}_{t}, \hat{\widetilde{c}}_{t-1},\left(\frac{\hat{W}}{P}\right)_{t},\left(\frac{\hat{W}}{P}\right)_{t-1}, \hat{K}_{t+1}, \hat{K}_{t}, \hat{K}_{t-1},\left(\frac{\hat{W}_{t+1}}{W_{t}}\right),\left(\frac{\hat{W}_{t}}{W_{t-1}}\right)\right\}$ to obtain $E_{t}\left[\hat{\theta}_{t+1}\right]$. Similarly to the treatment of $\hat{A}_{t}$, wc use the first-order autocorrelation of $E_{t}\left[\hat{\theta}_{t+1}\right]$ to estimate $\rho_{\theta}$, then divide $E_{f}\left[\hat{\theta}_{t+1}\right]$ by $\rho_{\theta}$ to obtain a series for $\hat{\theta}_{t}$. (We proceed in a similar manner for the model with sticky wages but no effort choice.)

Our monetary measure is based on calibrating nominal money demand and imposing, as is standard, that money supply equals demand. We then instrument for this variable with several financial variables and growth rates in monetary aggregates. This is discussed at length in Section 3 of the text. It is well known that given the estimated growth rate of any monetary aggregate, stochastic general equilibrium models generate nominal variables that are far more volatile than the data. We find that, for all three models considered, our measure of money also leads to far more volatility in prices than we see in the data. For this reason, we scale down the monetary disturbances to one-fifth their estimated size to match the volatility of price. 
Given the series for $\left\{\hat{A}_{t}, \hat{\theta}_{t}, \hat{\mu}_{t}\right\}$, the stochastic process (14)-(15) is estimated by OLS using annual data for the United States for 1960-1995. Linear time trends are included. Estimates for $\rho$ and $\Theta$ are as follows (with the monetary innovation scaled to one fifth). Under flexible wages,

$$
\hat{\rho}=\left[\begin{array}{ccc}
.90 & 0 & 0 \\
(.06) & .82 & \\
0 & (.09) & 0 \\
0 & 0 & .63 \\
& & (.13)
\end{array}\right], \quad \hat{\Theta}^{1 / 2}=10^{-2}\left[\begin{array}{ccc}
1.35 & .10 & -.11 \\
.10 & 1.41 & .01 \\
-.11 & .01 & .31
\end{array}\right]
$$

under sticky wages,

$$
\hat{\rho}=\left[\begin{array}{ccc}
.90 & 0 & 0 \\
(.06) & .86 & \\
0 & (.09) & 0 \\
0 & 0 & .63 \\
& & (.13)
\end{array}\right], \quad \hat{\Theta}^{1 / 2}=10^{-2}\left[\begin{array}{ccc}
1.29 & .42 & -.09 \\
.42 & 1.15 & -.08 \\
.09 & -.08 & .30
\end{array}\right]
$$

and under sticky wages with endogenous efforts,

$$
\hat{\rho}=\left[\begin{array}{ccc}
.93 & 0 & 0 \\
(.06) & & \\
0 & .86 & 0 \\
0 & (.09) & \\
0 & (.13)
\end{array}\right], \quad \hat{\Theta}^{1 / 2}=10^{-2}\left[\begin{array}{ccc}
1.43 & .21 & -.09 \\
.21 & 1.21 & -.09 \\
-.09 & -.09 & .30
\end{array}\right]
$$




\section{Appendix B: Cyclical moments for the models}

We now compare the moments for time series generated from each of the three models to those reported for U.S. data in Table 4. The generated series are also H-P filtered. The shocks to the models consist of the technology, preference, and monetary shocks estimated under each model, as described in Appendix A.

Results for the flexible wage model are contained in Tables Al and A2. The model generates fluctuations in output and hours that are respectively .82 and .78 times the size of those observed in the data. Labor productivity, by contrast, is somewhat more volatile for the model than in actual data. The model generates persistent movements in real variables, though, with the exception of labor productivity, not as persistent as in the data. The model generates much less persistent movements in prices than we see in the data. This statement holds as well for the other two models we consider. From Table A2 we see that the model generates contemporaneous correlations of labor productivity and TFP with hours of respectively -.05 and .40 . These are quite close to those estimated for U.S. data (.06 and .45). For the model movements in labor productivity and TFP modestly lag movements in hours. In the data, as discussed in the text, they very strongly lead hours.

Results under sticky wages and constant effort appear in Tables A3 and A4. Hours are more variable for the model than in the data. The sticky-wage model, even augmented with technology and preference shocks, fails to produce the observed persistence of economic time series. This is particularly true for hours, which display a first-order correlation of .53 in the data but only .05 for the sticky wage model. (This problem is well known in the literature. For a recent discussion see Chari, et. al., 1996.) From Table A4, the correlation between TFP and hours is .22. Unlike the data, hours and labor productivity are quite negatively correlated, with a correlation of -.42 compared to .06 for the data. Fluctuations in TFP do lead fluctuations in hours as in the data.

Finally, we present results for the model with sticky wages but varying effort in Tables A5 and A6. Broadly speaking, the time-series properties of this model are similar to those of the flexible wage model. Output is a bit more volatile than for the flexible wage model, and therefore closer to the volatility depicted in Table 3 for the U.S. economy. Looking at Table A6, the model generates a contemporaneous correlation between hours and labor productivity of -.16 and between hours and TFP of .13 Both correlations fall below those for the flexible wage model and below those for the data. This model does generate fluctuations in both labor productivity and TFP that lead those in hours worked. But this behavior is not as striking for the model as what we observe in the data. If we consider alternative parameters for the model that strengthen the importance of preference shocks, for example by reducing the elasticity response of labor supply, this creates a stronger leading pattern in labor productivity and TFP. But it also makes the contemporaneous correlation between hours and labor productivity more negative, in contradiction of the data.

The finding that TFP leads hours under sticky wages partly reflects the positive covariance between preference and productivity shocks. In particular, if we set the covariance of the two real shocks equal to zero, then productivity does not lead hours under sticky wages with constant effort. In response to an increase in $\theta$ consumption increases causing prices to decrease. With a sticky wage this initially increases the real wage and, under constant effort, decreases hours. But this is transitory; hours expand after nominal wages can respond-see figure $4 \mathrm{~b}$. If the preference shock 
is positively correlated with the technology shock then TFP leads hours. TFP goes up due to the technology shock. The delayed response in hours reflects the preference shock. These effects are relevant, but less important, for our sticky-wage model with an effort response. With responses in effort, productivity leads hours even if the covariance between the two real shocks is zero, though this effect is less striking. 


\section{Appendix C: Welfare costs of wage stickiness}

Monetary disturbances are essentially neutral with respect to flexible-wage versions of the model. Therefore, for monetary disturbances, the welfare cost of sticky wages can be measured based on the economy's deviations from its steady state. Let $\bar{U}$ denote the lifetime utility associated with consumption of goods, real balances, and leisure for the economy calculated at its steady-state level. Similarly, let $U_{s}$ denote lifetime utility for the realizations of the economy under sticky wages. Then $\hat{U}=U_{s}-\bar{U}=\sum_{\tau=0}^{\infty} \beta^{r-t} E_{t}\left[\hat{u}_{\tau}\right]$, where $\hat{u}_{t}$ is the utility cost incurred in $t$.

Let $D_{s}$ represent the welfare cost from sticky wages in consumption units, so that $\log \left(x-D_{s}\right)-\log x=\hat{U}$. We can express $D_{s}$ in terms relative to steady-state consumption as $\frac{D_{s}}{x}=1-e^{\hat{U}}$.

Ignoring money balances, which are unimportant, the period $t$ utility cost can be written

$$
E\left[\hat{u}_{t}\right]=E\left[\theta \log c_{t}+(1-\theta) \log \tilde{l}_{l}\right]-[\theta \log c+(1-\theta) \log \tilde{l}],
$$

where $c$ and $\tilde{l}$ are steady state values. Its second-order Taylor approximation is

$$
E\left[\hat{u}_{t}\right] \approx \frac{\theta}{c} E\left(c_{t}-c\right)+\frac{1-\theta}{\tilde{l}} E(\tilde{l}-\tilde{l})-\frac{1}{2} \frac{O}{c^{2}} E\left(c_{t}-c\right)^{2}-\frac{1}{2} \frac{1-\theta}{\tilde{l}^{2}} E(\tilde{l} t-\tilde{l})^{2} .
$$

Generally speaking, $E\left[c_{1}\right] \neq c$ under sticky wages. We approximate $E\left[c_{l}\right]$ as follows (ignoring productivity shifts).

$$
\begin{aligned}
& E\left[c_{t}\right] \approx S_{c} E\left[y_{t}\right]=S_{c} E\left[L_{t}\left(\frac{K}{L}\right)_{t}^{1-\alpha}\right] \\
& \approx S_{c} E\left[L\left(\frac{K}{L}\right)^{1-\alpha}+\left(\frac{K}{L}\right)^{1-\alpha}\left(L_{t}-L\right)+L(1-\alpha)\left(\frac{K}{L}\right)^{-\alpha}\left(\left(\frac{K}{L}\right)_{t}-\frac{K}{L}\right)\right. \\
& \left.-\frac{1}{2} \alpha(1-\alpha) L\left(\frac{K}{L}\right)^{-\alpha-1}\left(\left(\frac{K}{L}\right)_{t}-\frac{K}{L}\right)^{2}+(1-\alpha)\left(\frac{K}{L}\right)^{-\alpha}\left(\left(\frac{K}{L}\right)_{t}-\frac{K}{L}\right)\left(L_{t}-L\right)\right]
\end{aligned}
$$

where $L_{t}=N_{t} \Phi^{r}$, and $S_{c}$ is the ratio of consumption to output in steady-state.

Finally, $\hat{u}_{t}$ can be expressed in terms of percentage deviations of variables from steadystate as

$$
E\left[\hat{u}_{t}\right] \approx-\frac{1}{2} \theta E\left[\hat{c}_{l}\right]^{2}-\frac{1}{2}(1-\theta) E\left[\hat{\tilde{l}}_{l}\right]^{2}-\frac{1}{2} O S_{c} \alpha(1-\alpha) E\left[\left(\frac{\hat{K}}{L}\right)_{l}\right]^{2}+\theta S_{c}(1-\alpha) E\left[\left(\frac{\hat{K}}{L}\right)_{l} \hat{L}_{t}\right] .
$$




\section{References}

Altonji, Joseph (1986) "Intertemporal Substitution in Labor Supply: Evidence from Micro Data," Journal of Political Economy, 94, s176-s215.

Baxter, Mariane and Robert King (1991) "Productive Externalities and Business Cycles," Discussion paper 53, Institute for Empirical Macroeconomics, Federal Reserve Bank of Minneapolis.

Becker, Gary (1965) "A Theory of the Allocation of Time," Economic Journal 73, 493-508.

Becker, Gary (1985) "Human Capital, Effort, and the Sexual Division of Labor," Journal of Labor Economics, 3, S33-S58.

Bernanke, Ben and Alan Blinder (1988) "The Federal Funds Rate and the Channels of Monetary Transmission," American Economics Review 82, 901-921.

Bils, Mark and Jang-Ok Cho (1994) "Cyclical Factor Utilization," Journal of Monetary Economics, 33 (2) 319-54.

Bureau of Labor Statistics (1944) Studies of the Effects of Long Working Hours, BLS Bulletins 791 and $791 \mathrm{~A}$.

Bureau of Labor Statistics (1947) Hours of Work and Output, BLS Bulletin 917.

Bureau of Labor Statistics (1993) Labor Composition and U.S. Productivity Growth, 1948-90, BLS Bulletin 2426.

Burnside, Craig, Martin Eichenbaum, and Sergio Rebelo (1993) "Labor Hoarding and the Business Cycle," Journal of Political Economy 101, 245-273.

Chari, V.V. Patrick Kehoe and Ellen McGrattan (1996) "Sticky Price Models of the Business Cycle: Can the Contract Multiplier Solve the Persistence Problem?" NBER Working Paper No. 5809.

Cho, Jang-Ok, Thomas Cooley, and Louis Phaneuf (1997) "Welfare Costs of Nominal Contracts," Review of Economic Studies 64, 465-484.

Christiano, Lawrence, Martin Eichenbaum, and Charles Evans (1996) "The Effects of Monetary Policy Shocks: Evidence from the Flow of Funds, Review of Economics and Statistics 78, 16-34. 
Ghez, G. R. and Gary Becker (1975) The Allocation of Time and Goods over the Life Cycle, New York: National Bureau of Economic Research, Columbia University Press.

Goldmark, Josephine (1912) Fatigue and Efficiency. New York: Russell Sage Foundation.

Hall, Robert (1986) "The Role of Consumption in Economic Fluctuations," in R. J. Gordon (ed.) The American Business Cycle: Contimuity and Change. Chicago: University of Chicago Press.

Hartley, Peter (1992) "The Effect of Minimum Wage Laws on Labour Markets," in Proceedings of the H.R. Nicholls Society, Vol. 13, Melbourne, Australia.

Hill, Martha (1985) "Patterns of Time Use," in Time, Goods and Well-Being, edited by F. Thomas Juster and Frank P. Stafford. Ann Arbor: University of Michigan.

King, Robert, Charles Plosser and Sergio Rebelo (1988) "Production, Growth and Business Cycles: I. The Basic Neoclassical Model," Journal of Monetary Economics, 21, 195-232.

Laidler, David (1985) The Denand for Money: Theories and Evidence, $3^{\text {rd }}$ Edition. New York: Harper and Row.

Mankiw, Gregory (1997) Macroeconomics. New York: Worth Publishers.

MaCurdy (1981) "An Empirical Model of Labor Supply in a Life-Cycle Setting," Journal of Political Economy, 89, 1059-1085.

Oi, Walter Y. (1990) "Employment Relations in Dual Labor Markets ('It's Nice Work if You Can Get It')," Journal of Labor Economics, 8, S124-S149.

Parkin, Michael (1988), "A Method for Determining whether Parameters in Aggregative Models are Structural," Carnegie-Rochester Conference on Public Policy, 29, 215-252.

Passmore, Reginald, B.M. Nichol, and M. Narayana Rao (1974) Handbook on Human Nutritional Requirements. Geneva: World Health Organization.

Sims, Christopher and Tao Zha (1994) "Does Monetary Policy Generate Recessions?," Manuscript, Yale University.

Strongin, Steven (1992) "The Identification of Monetary Policy Disturbances: Explaining the Liquidity Puzzle, Journal of Monetary Economics 35, 463-498. 
</ref_section> 
Table 1 - Energy Expenditures (in kilo-calories per 8 hours) for Sleeping, Non-work Activities, and Working, from Passmore, et. al., Handbook on Human Nutritional Requirements (1974)

\begin{tabular}{l|cc}
\hline & $65 \mathrm{Kg}$ Man & $55 \mathrm{Kg}$ Woman \\
\hline Sleeping & 500 & 420 \\
Non-working Activities & $700-1500$ & $580-980$ \\
Working Activities* & & \\
Light & 1100 & 800 \\
Moderately active & 1400 & 1000 \\
Very active & 1900 & 1400 \\
Exceptionally active & 2400 & 1800 \\
\hline
\end{tabular}

* Classifications of occupations by intensity:

Light

Men: Office workers, professionals (lawyers, doctors, accountants, teachers, etc.), shop workers.

Women: Office workers, housewives with mechanical household appliances, teachers and most other professionals

Moderately active

Men: Men in light industry, students, construction workers (excluding heavy laborers), many farm workers, soldiers on inactive service, fisherman.

Women: Women in light industry, housewives without mechanical household appliances, students, department-store workers.

Very active

Men: Some agricultural workers, unskilled laborers, forestry workers, army recruits, soldiers on active service, mine workers, steel workers, athletes.

Women: Some farm workers (especially in pcasant agriculture), dancers, athletes.

Exceptionally active

Men: Lumberjacks, blacksmiths, rickshaw pullers.

Women: Construction workers. 
Table 3 - Results from Studying the Impact of Reduced Workweeks on Productivity of Piece-Rate Workers, described in Goldmark, Fatigue and Efficiency (1912)

\begin{tabular}{|c|c|c|}
\hline Case & Description & Results \\
\hline $\begin{array}{l}\text { Salford Iron Works, } \\
\text { Manchester England, } 1893\end{array}$ & $\begin{array}{l}\text { March } 1,1893 \text {, reduce weekly } \\
\text { hours from } 53 \text { to } 48 \text {. } \\
\text { Productivity for } 3 / 1 / 93 \text { to } 2 / 28 / 94 \\
\text { compared to previous six years. }\end{array}$ & $\begin{array}{l}\text { Hours reduced by } \\
\text { almost } 10 \text { percent } \\
\text { Productivity (per } \\
\text { hour) increased by } \\
\text { about } 8.8 \text { percent. }\end{array}$ \\
\hline $\begin{array}{l}\text { Engis Chemical Works, } \\
\text { near } \\
\text { Liége, Belgium, } 1893^{*}\end{array}$ & $\begin{array}{l}\text { Beginning } 1893 \text { change from } 2- \\
\text { shift production to } 3 \text {-shift } \\
\text { production, reduce daily hours } \\
\text { from } 10 \text { to } 8 \text {. } \\
\text { Productivity for } 1893 \text { compared to } \\
1889-1892 \text {. }\end{array}$ & $\begin{array}{l}\text { Hours reduced by } 20 \\
\text { percent. } \\
\text { Productivity increased } \\
\text { by } 12.4 \text { percent. }\end{array}$ \\
\hline $\begin{array}{l}\text { Zeiss Optical Works, Jena, } \\
\text { Germany, } 1900^{\dagger}\end{array}$ & $\begin{array}{l}\text { April } 1,1900 \text { daily hours reduced } \\
\text { from } 9 \text { to } 8 \text {. } \\
\text { Productivity for } 4 / 1 / 99 \text { to } 3 / 31 / 00 \\
\text { compared to } 4 / 1 / 00 \text { to } 3 / 31 / 01 \text {. }\end{array}$ & $\begin{array}{l}\text { Hours reduced by } \\
\text { about } 11 \text { percent. } \\
\text { Productivity increased } \\
\text { by } 16 \text { percent. } \\
\text { (Results are similar } \\
\text { across ages and } \\
\text { occupations.) }\end{array}$ \\
\hline
\end{tabular}

* L.G. Fromont, the engineer who founded and managed the Engis works reported his findings on the shortened workweek to the Belgian Chemical Society and the Association of Enginers of the Liége School in 1897.

${ }^{\dagger}$ Ernst Abbé, a physicist, university professor, inventor, and owner of the Zeiss Optical Works, reported his results in two lectures before the Society for Political Economy of Jena in 1901. 
Table 2 - Response of Productivity to Hours Worked

\begin{tabular}{|c|c|c|c|}
\hline & Column 1 & Column 2 & Column 3 \\
\hline Intercept & $\begin{array}{r}.047 \\
(.011)\end{array}$ & $\begin{array}{c}.045 \\
(.009)\end{array}$ & $\begin{array}{c}.042 \\
(.008)\end{array}$ \\
\hline$\Delta$ Hours & -.123 & -.264 & -.250 \\
\hline Hours & $(.065)$ & $(.069)$ & $(.059)$ \\
\hline$\Delta \mathrm{War}$ & & $\begin{array}{c}.056 \\
(.014)\end{array}$ & \\
\hline$\Delta W a r \bullet W a r$ related & & & $\begin{array}{r}.080 \\
(.015)\end{array}$ \\
\hline $\bar{R}^{2}$ & .04 & .22 & .34 \\
\hline $\mathrm{N}$ & 62 & 62 & 62 \\
\hline
\end{tabular}


Table 4 - Parameter Values for the Benchmark Case

\begin{tabular}{l|l}
\hline Parameters & Description \\
\hline$\alpha=2 / 3$ & Labor share in output \\
$\beta=0.98$ & Discount factor \\
$\delta=0.1$ & Depreciation rate \\
$\mathrm{g}=0.02$ & Growth rate of technological progress \\
$\xi=1$ & Labor supply elasticity \\
$\mathrm{n}=0.5$ & Steady-state hours of work \\
$\phi / \tilde{\phi}=3 / 2$ & Ratio of effort in the market and home \\
$\gamma=1 / 3$ & Ability to substitute hours and effort in the market \\
$\lambda=1 / 4$ & Ability to substitute hours and effort at home \\
$\mathrm{v}=.1$ & Interest rate elasticity of money demand \\
$\chi=.9999$ & Relative share of consumption in utility \\
$\theta=0.6332$ & Steady-state value in preference \\
\hline
\end{tabular}


Table 5 - Volatility, persistence, and cyclicality: U.S. time series 1954-1996"

\begin{tabular}{l|lcll}
\hline Variable $(\mathrm{x})$ & \multicolumn{1}{|l}{$\sigma_{\mathrm{x}}$} & $\sigma_{\mathrm{x}} / \sigma_{\text {oulput }}$ & $\operatorname{cor}\left(\mathrm{x}_{\mathrm{t}}, \mathrm{x}_{\mathrm{t}-1}\right)$ & $\operatorname{cor}(\mathrm{x}$, output $)$ \\
\hline Output & 2.29 & 1.00 & .57 & 1.00 \\
Consumption & 1.32 & .58 & .67 & .88 \\
Investment & 6.39 & 2.79 & .41 & .83 \\
Hours & 2.01 & .88 & .53 & .91 \\
Price & .97 & .42 & .81 & -.57 \\
Real wage & .94 & .44 & .48 & .49 \\
Labor productivity & .97 & .42 & .46 & .48 \\
Solow residual & 1.29 & .57 & .45 & .82 \\
\hline
\end{tabular}

Table 6 - Lead and Lag correlations with hours at $t$.

\begin{tabular}{l|ccccccc}
\hline Variable $(\mathrm{x})$ & $\mathrm{x}(\mathrm{t}-3)$ & $\mathrm{x}(\mathrm{t}-2)$ & $\mathrm{x}(\mathrm{t}-1)$ & $\mathrm{x}(\mathrm{t})$ & $\mathrm{x}(\mathrm{t}+1)$ & $\mathrm{x}(\mathrm{t}+2)$ & $\mathrm{X}(\mathrm{t}+3)$ \\
\hline Real wage & -.28 & -.01 & .38 & .43 & -.09 & -.36 & -.28 \\
Labor productivity & .14 & .54 & .65 & .06 & -.38 & -.23 & -.14 \\
Solow residual & .16 & .51 & .76 & .45 & -.28 & -.46 & -.39 \\
\hline
\end{tabular}

\# Output: real GDP. Consumption: expenditure on non-durables and services. Investment: fixed investment. Hours: employed man-hours. Real wage: average hourly earning. Labor productivity: output divided by hours. Quantities are divided by population of age over 20. All variables are annual and H-P filtered with the weight parameter 100 . 
Table A5 - Volatility, persistence, and cyclicality: Sticky wages \& effort response

\begin{tabular}{l|llll}
\hline Variable $(\mathrm{x})$ & $\sigma_{\mathrm{x}}$ & $\sigma_{\mathrm{x}} / \sigma_{\text {ouput }}$ & $\operatorname{cor}\left(\mathrm{x}_{\mathrm{t}}, \mathrm{x}_{\mathrm{l}-1}\right)$ & $\operatorname{cor}(\mathrm{x}$, output $)$ \\
\hline Output & 2.03 & 1.00 & .44 & 1.00 \\
Consumption & 1.40 & .69 & .48 & .95 \\
Investment & 3.89 & 1.91 & .40 & .96 \\
Hours & 1.53 & .75 & .35 & .60 \\
Price & 1.60 & .78 & .50 & -.90 \\
Labor productivity & 1.61 & .79 & .12 & .66 \\
TFP & 1.61 & .79 & .20 & .85 \\
\hline
\end{tabular}

Table A6 - Lead and lag correlations with hours at $t$ : Sticky wages \& effort response

\begin{tabular}{l|llllllc}
\hline Variable $(\mathrm{x})$ & $\mathrm{x}(\mathrm{t}-3)$ & $\mathrm{x}(\mathrm{t}-2)$ & $\mathrm{x}(\mathrm{t}-1)$ & $\mathrm{x}(\mathrm{t})$ & $\mathrm{x}(\mathrm{t}+1)$ & $\mathrm{x}(\mathrm{t}+2)$ & $\mathrm{x}(\mathrm{t}+3)$ \\
\hline Labor productivity & -.01 & .10 & .33 & -.16 & -.04 & .00 & .01 \\
TFP & -.02 & .15 & .48 & .13 & .00 & -.07 & -.10 \\
\hline
\end{tabular}


Table A3 - Volatility, persistence, and cyclicality: Sticky wages \& constant effort

\begin{tabular}{l|llll}
\hline Variable $(\mathrm{x})$ & $\sigma_{\mathrm{x}}$ & $\sigma_{\mathrm{x}} / \sigma_{\text {oulput }}$ & $\operatorname{cor}\left(\mathrm{x}_{\mathrm{t}}, \mathrm{x}_{\mathrm{t}-1}\right)$ & $\operatorname{cor}(\mathrm{x}$, output $)$ \\
\hline Output & 2.10 & 1.00 & .37 & 1.00 \\
Consumption & 1.22 & .58 & .50 & .73 \\
Investment & 5.46 & 2.60 & .10 & .92 \\
Hours & 2.29 & 1.09 & .05 & .82 \\
Price & 1.40 & .66 & .54 & -.69 \\
Labor productivity & 1.31 & .62 & .08 & .14 \\
TFP & 1.21 & .57 & .39 & .71 \\
\hline
\end{tabular}

Table A4 - Lead and lag correlations with hours at $t$ : Sticky wages \& constant effort

\begin{tabular}{l|ccccccc}
\hline Variable $(\mathrm{x})$ & $\mathrm{x}(\mathrm{t}-3)$ & $\mathrm{x}(\mathrm{t}-2)$ & $\mathrm{x}(\mathrm{t}-1)$ & $\mathrm{x}(\mathrm{t})$ & $\mathrm{x}(\mathrm{t}+1)$ & $\mathrm{x}(\mathrm{t}+2)$ & $\mathrm{x}(\mathrm{t}+3)$ \\
\hline Labor productivity & -.02 & .11 & .32 & -.42 & .10 & .08 & .07 \\
TFP & -.06 & .14 & .45 & .22 & .04 & -.06 & -.09 \\
\hline
\end{tabular}


Table Al - Volatility, persistence, and cyclicality: Flexible wages

\begin{tabular}{l|llll}
\hline Variable $(\mathrm{x})$ & $\sigma_{\mathrm{x}}$ & $\sigma_{\mathrm{x}} / \sigma_{\text {output }}$ & $\operatorname{cor}\left(\mathrm{x}_{\mathrm{t}}, \mathrm{x}_{\mathrm{t}-1}\right)$ & $\operatorname{cor}(\mathrm{x}$, output $)$ \\
\hline Output & 1.89 & 1.00 & .41 & 1.00 \\
Consumption & 1.27 & .67 & .47 & .93 \\
Investment & 3.80 & 2.00 & .37 & .95 \\
Hours & 1.58 & .83 & .35 & .79 \\
Price & 1.38 & .72 & .51 & -.88 \\
Labor productivity & 1.13 & .59 & .44 & .54 \\
TFP & 1.20 & .63 & .39 & .85 \\
\hline
\end{tabular}

Table A2 - Lead and lag correlations with hours at $t$ : Flexible wages

\begin{tabular}{l|lllllll}
\hline Variable $(\mathrm{x})$ & $\mathrm{x}(\mathrm{t}-3)$ & $\mathrm{x}(\mathrm{t}-2)$ & $\mathrm{x}(\mathrm{t}-1)$ & $\mathrm{x}(\mathrm{t})$ & $\mathrm{x}(\mathrm{t}+1)$ & $\mathrm{x}(\mathrm{t}+2)$ & $\mathrm{x}(\mathrm{t}+3)$ \\
\hline Labor productivity & -.09 & -.10 & -.09 & -.05 & .12 & .15 & .11 \\
TFP & -.10 & -.03 & .12 & .40 & .20 & .05 & -.04 \\
\hline
\end{tabular}


Figure 1 Labor market equilibrium: sticky wage with effort

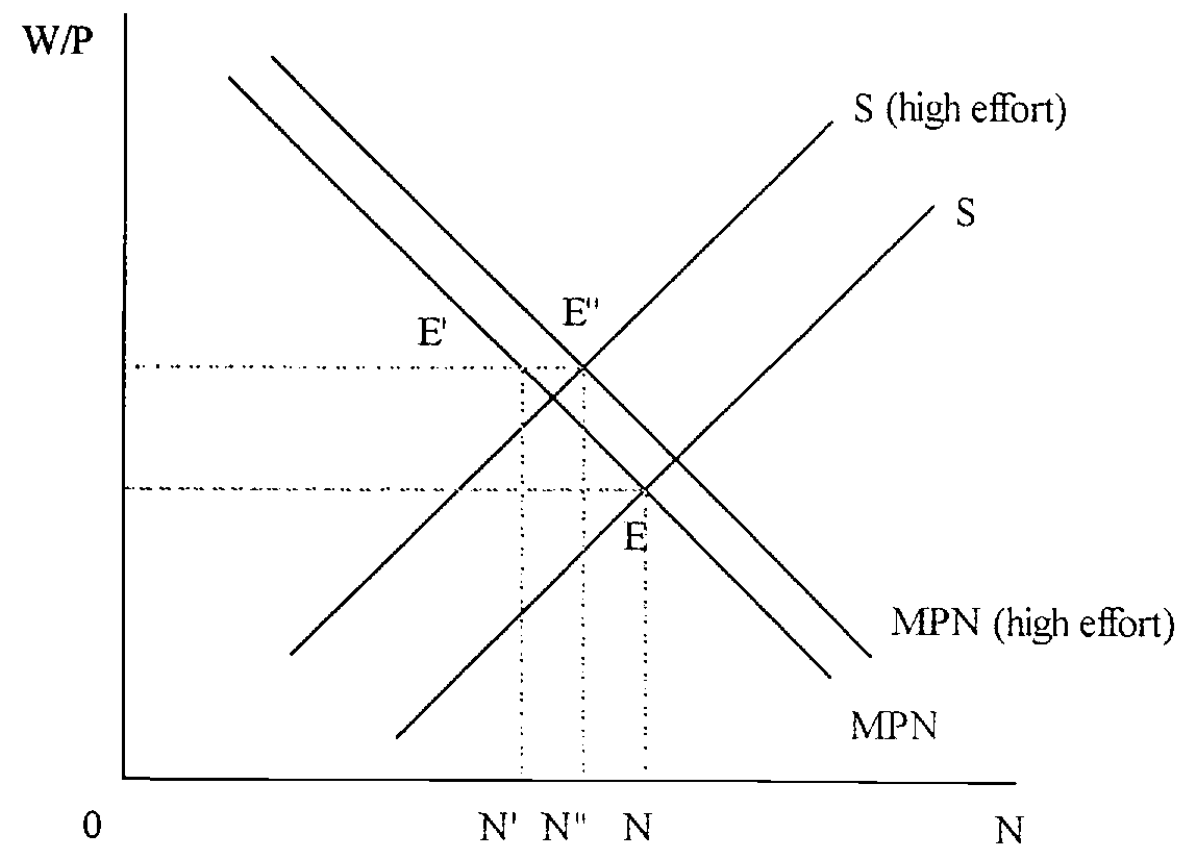


Figure 2a Impulse response of VAR: inflation rate and TFP
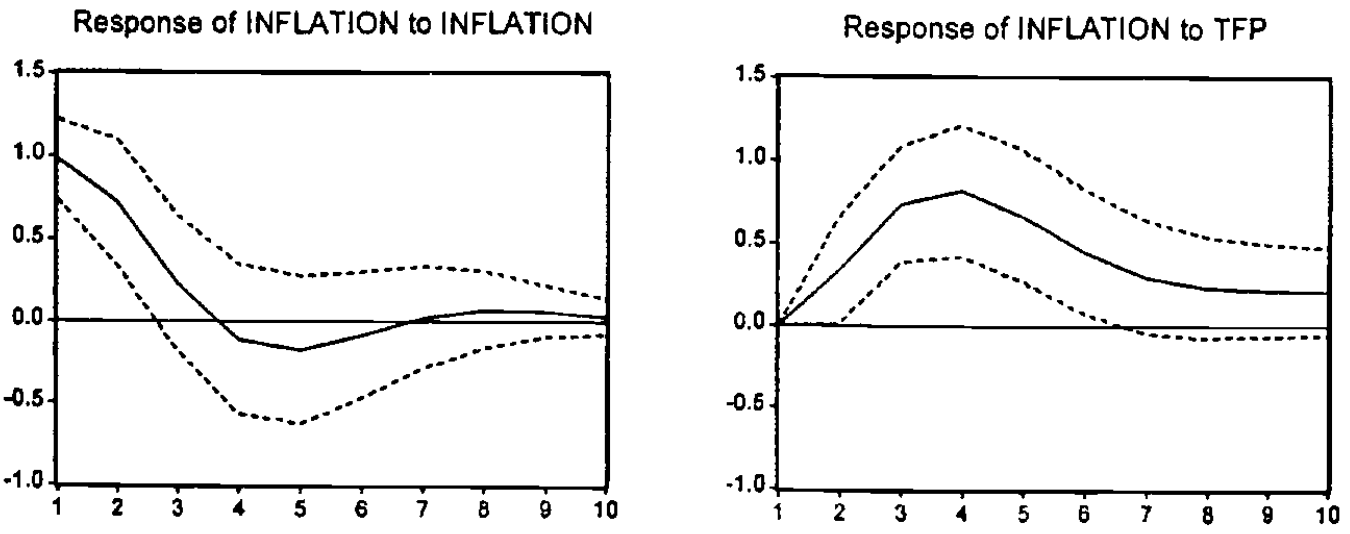

Response of TFP to INFLATION

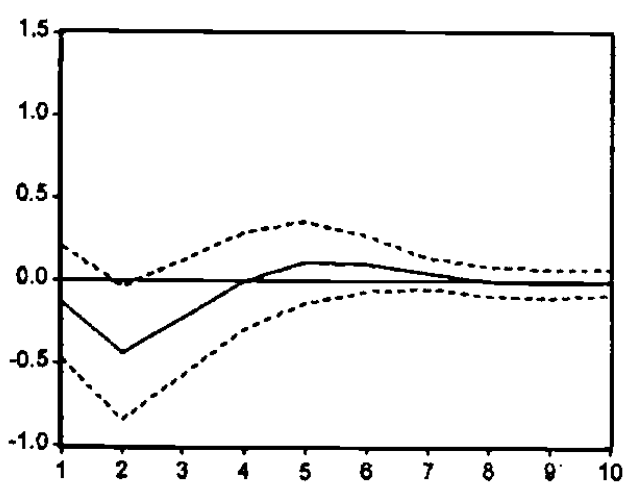

Response of TFP to TFP

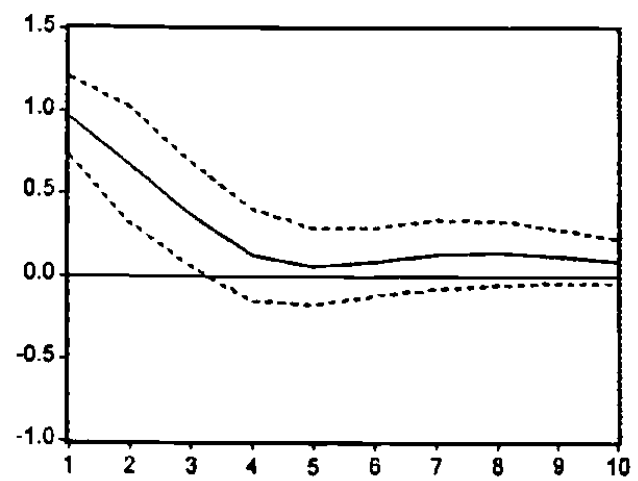


Figure $2 \mathrm{~b}$ Impulse response of VAR: growth rate of money measure and TFP

Response of MONEY to MONEY

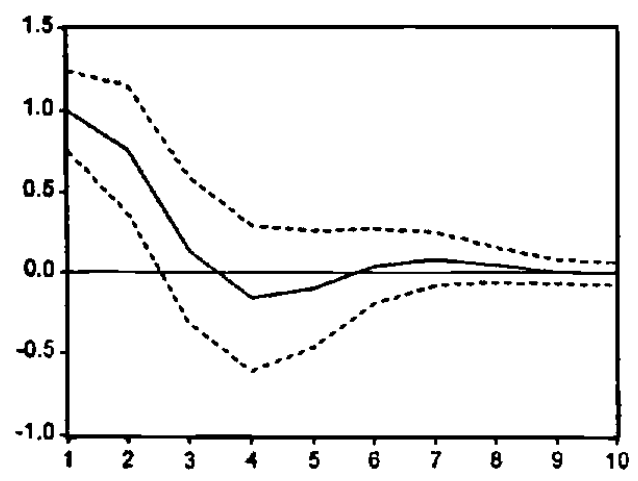

Response of TFP to MONEY

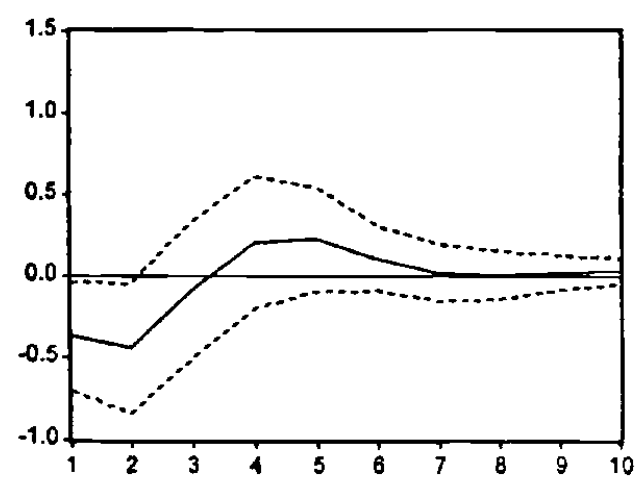

Response of MONEY to TFP

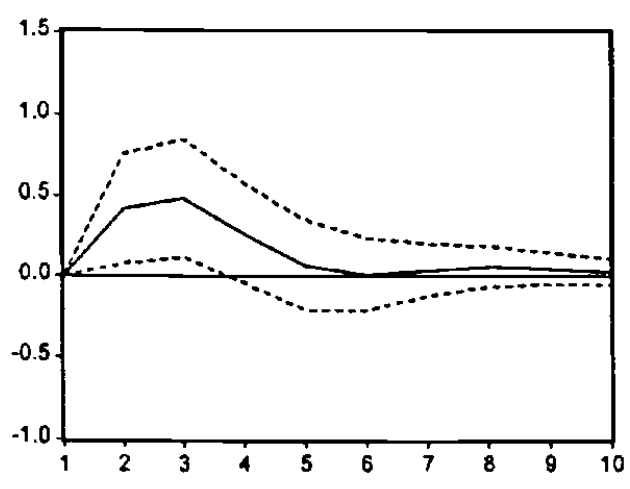

Response of TFP to TFP

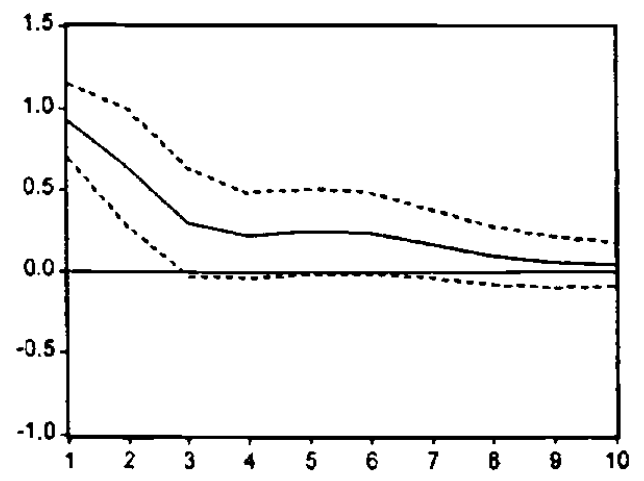


Figure 3 a Impulse response to $1 \%$ increase in productivity: flexible wage
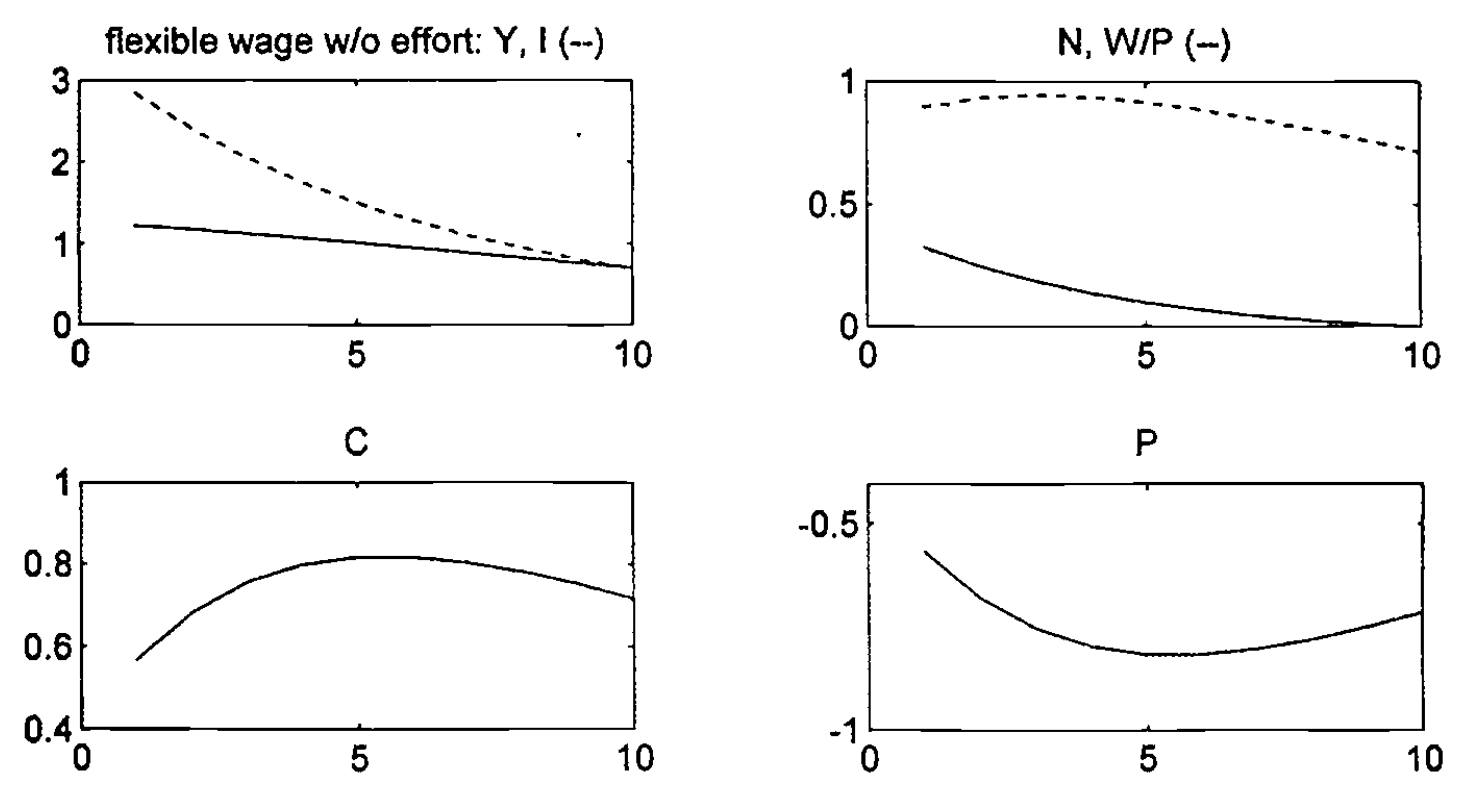
Figure $3 \mathrm{~b}$ Impulse response to $1 \%$ increase in productivity: sticky wage
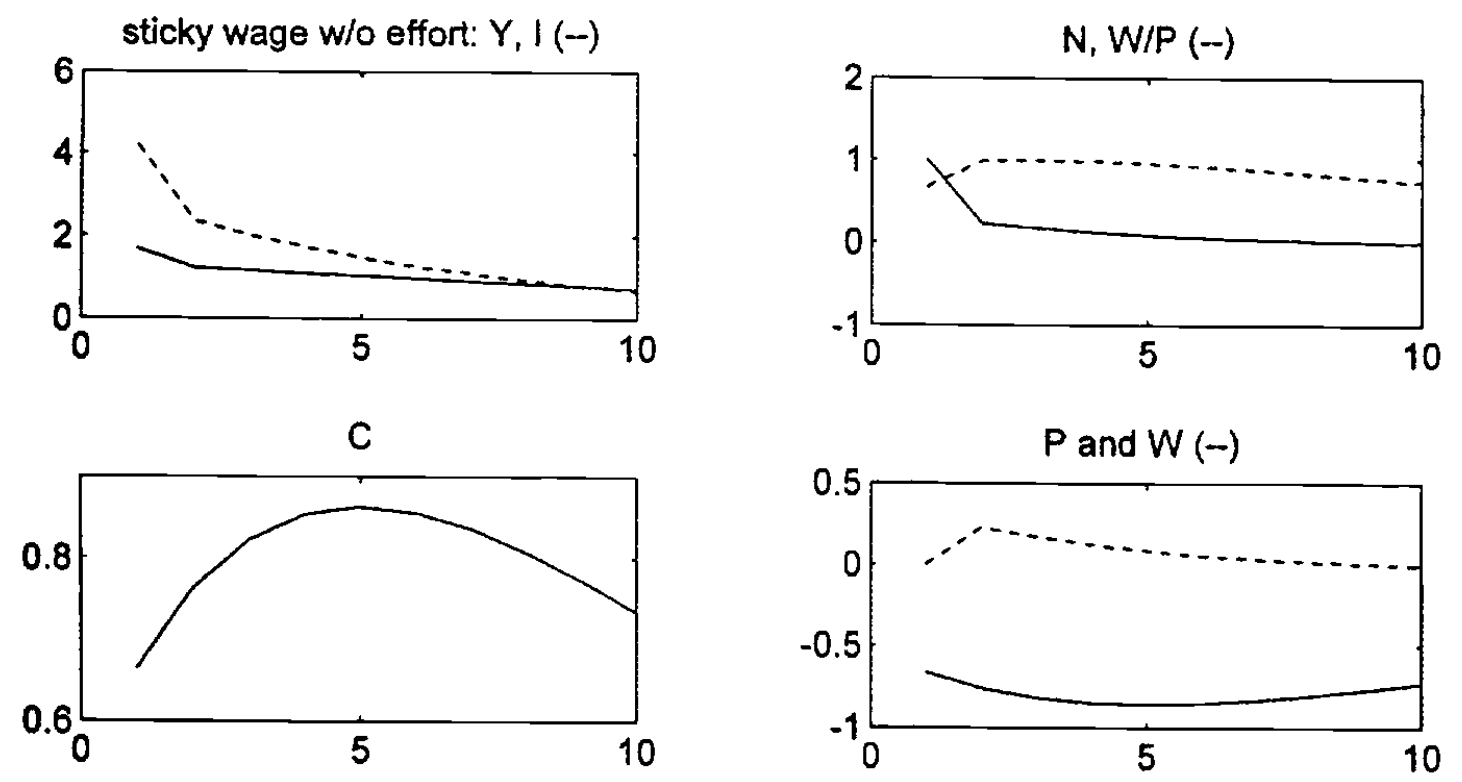
Figure $3 \mathrm{c}$ Impulse response to $1 \%$ increase in productivity: sticky wage with effort
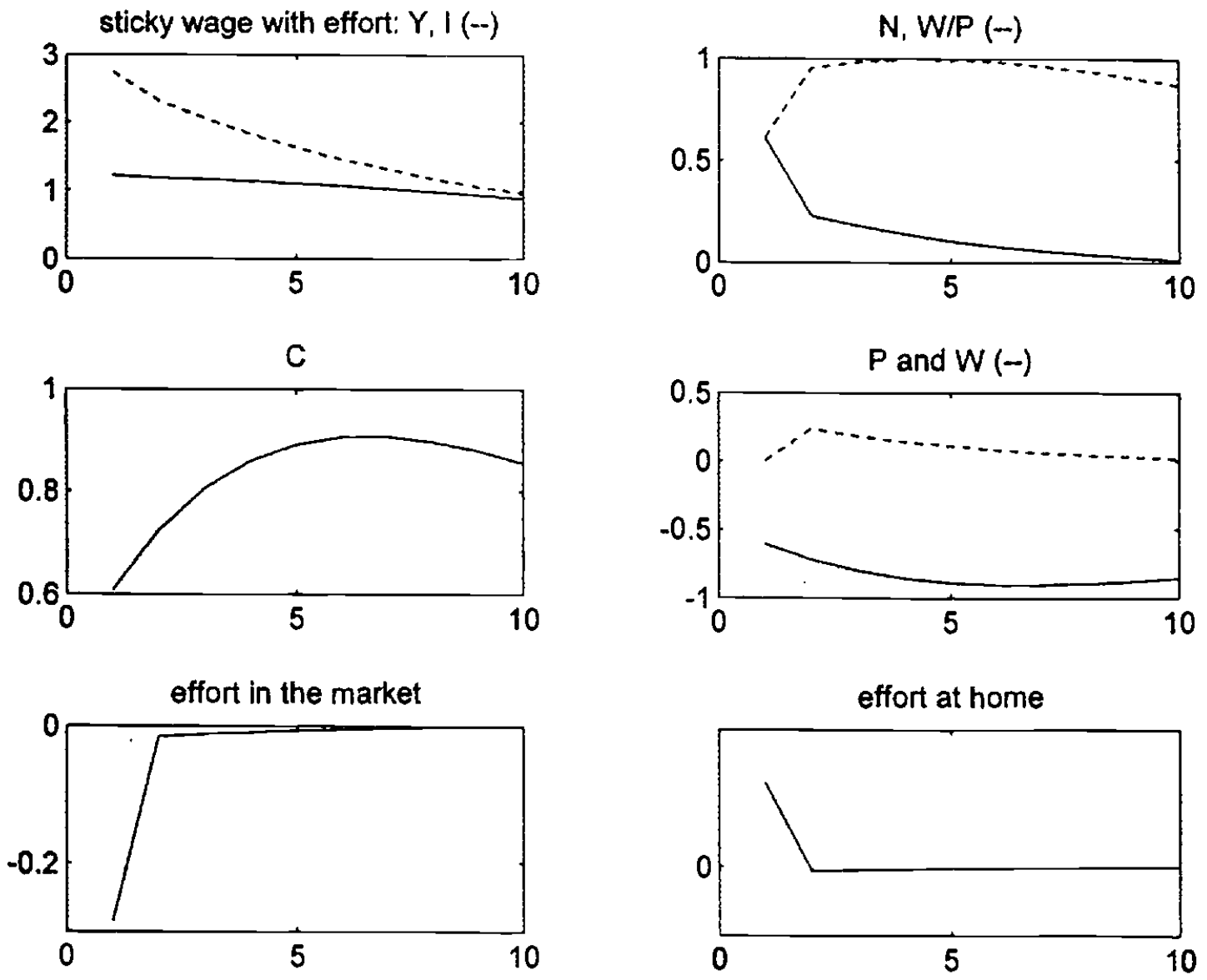
Figure $4 \mathrm{a}$ Impulse response to $1 \%$ increase in preference shock: flexible wage
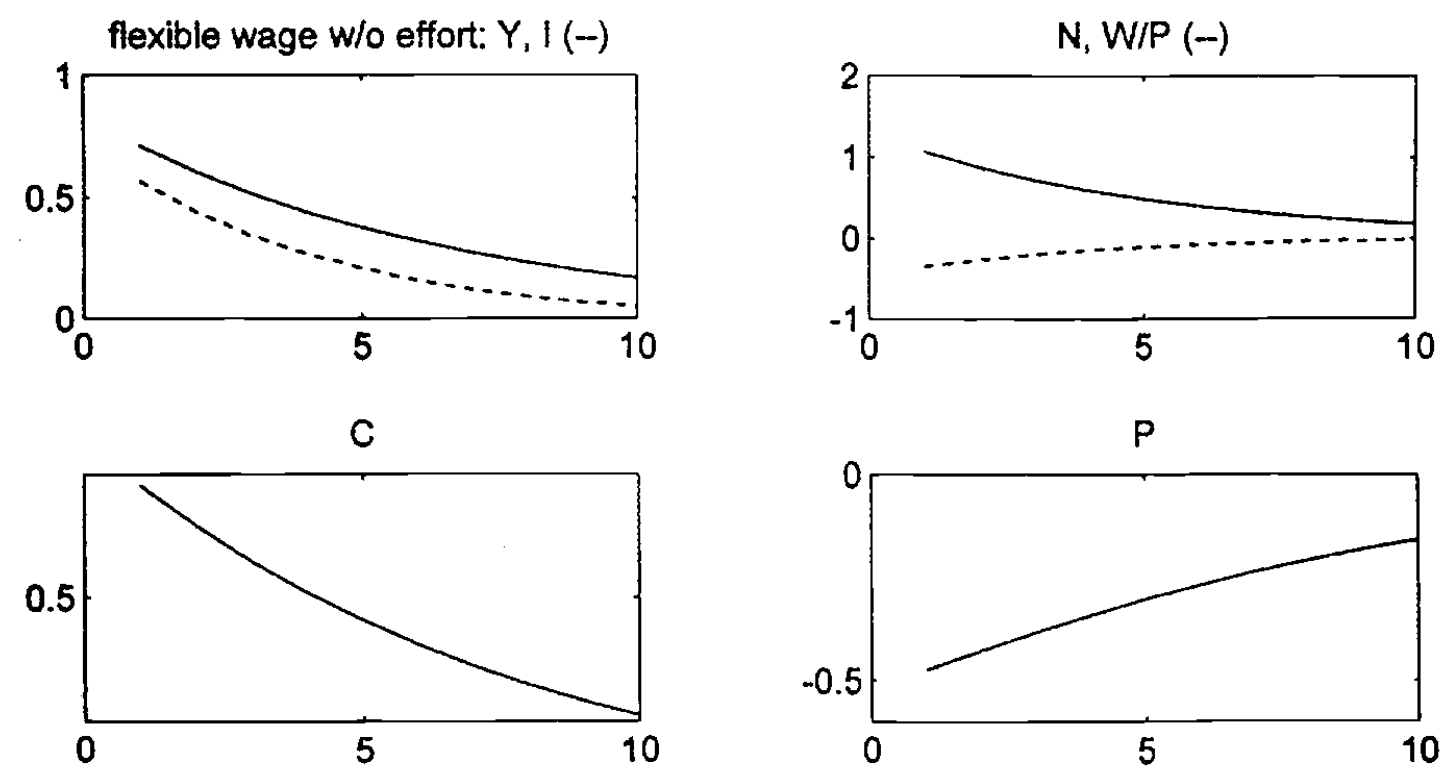
Figure $4 \mathrm{~b}$ Impulse response to $1 \%$ increase in preference shock: sticky wage
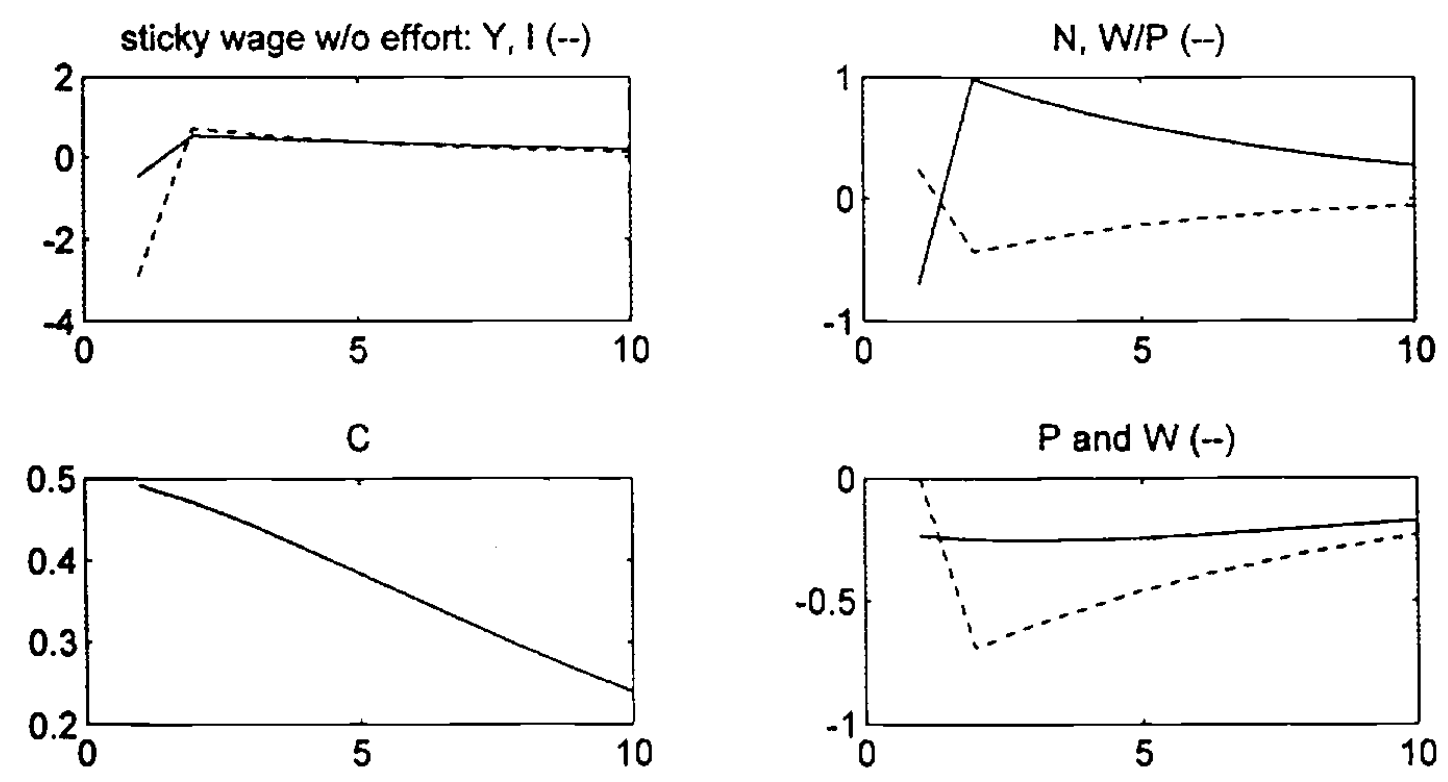
Figure $4 \mathrm{c}$ Impulse response to $1 \%$ increase in preference shock: sticky wage with effort
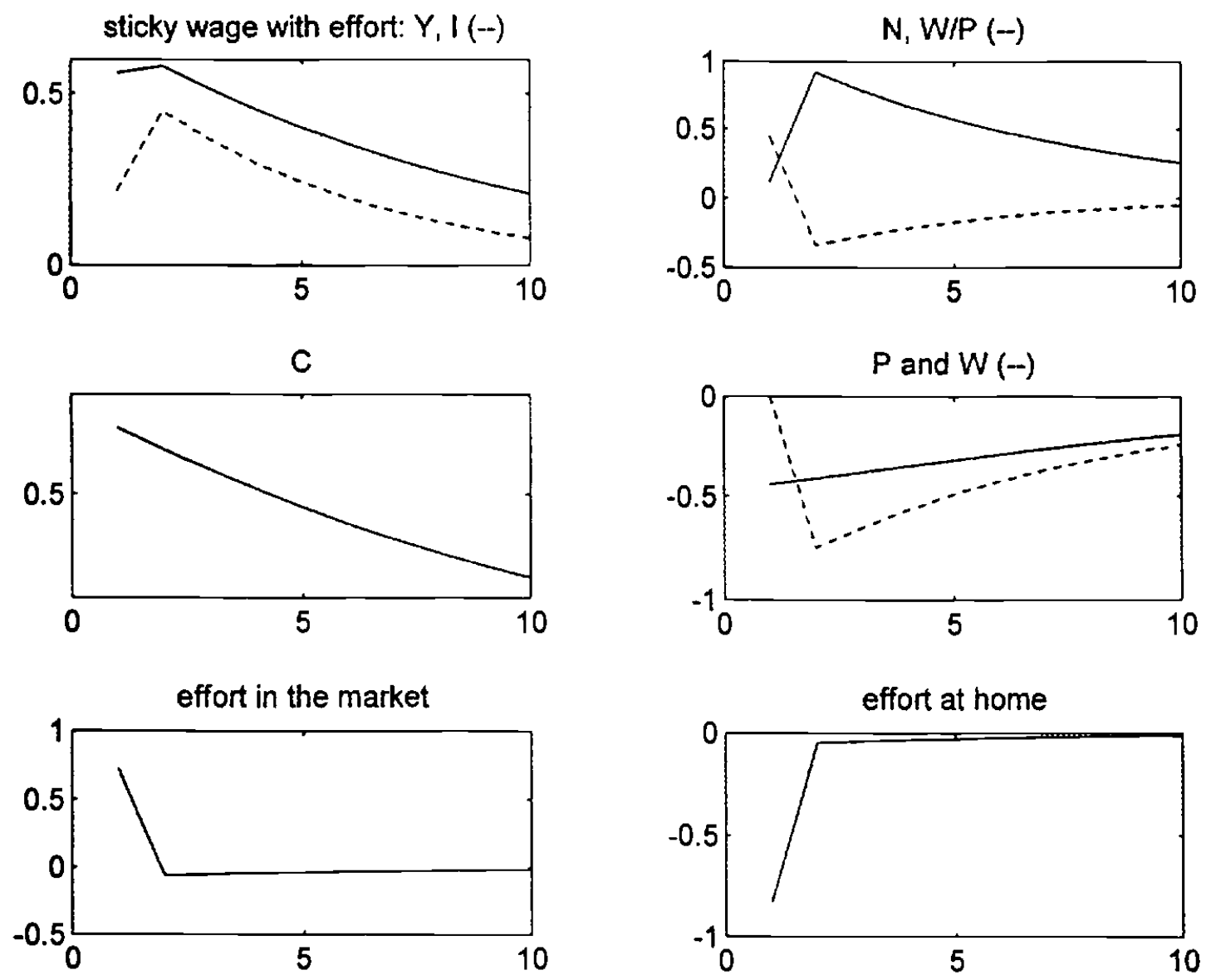
Figure 5a Impulse response to $1 \%$ increase in money growth: sticky wage
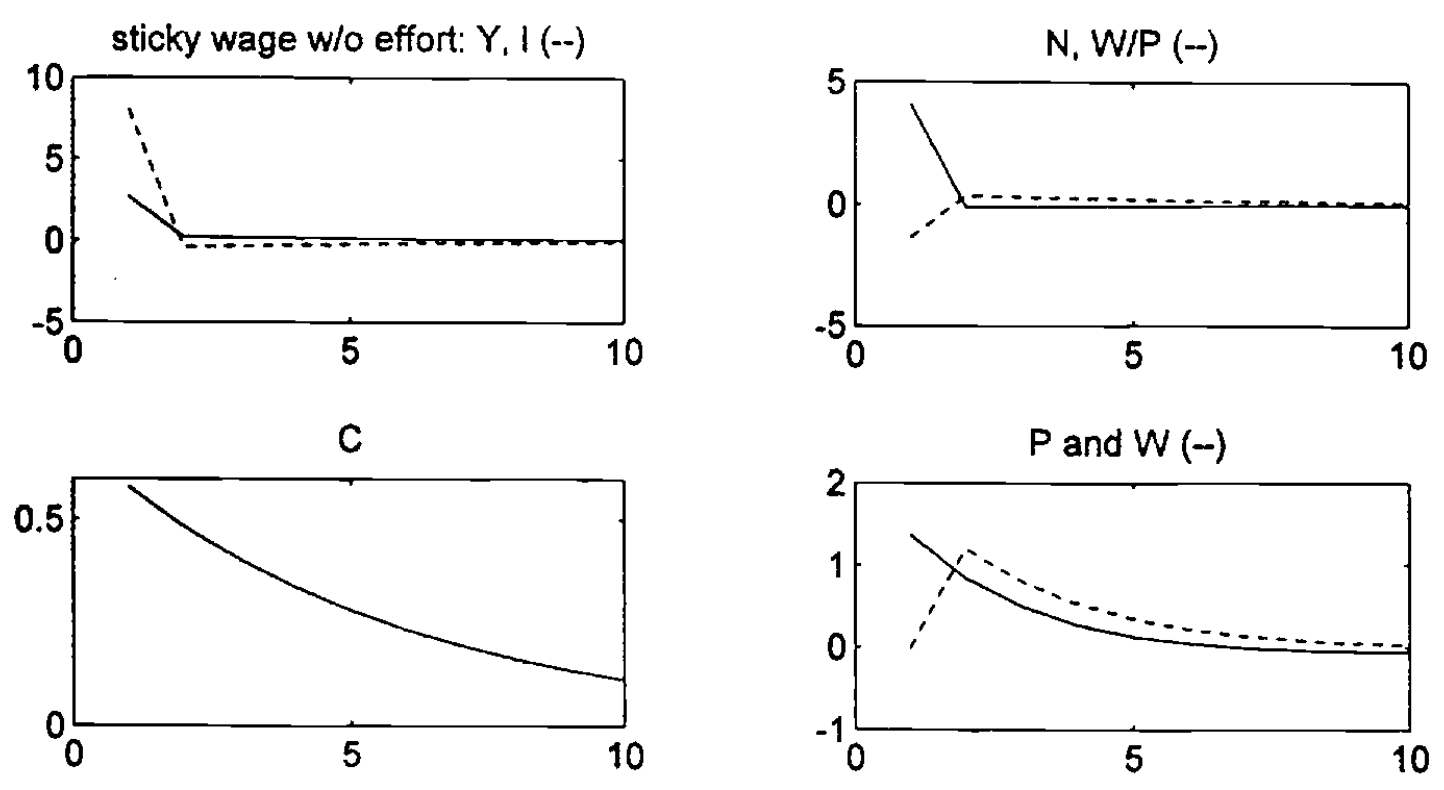
Figure $5 \mathrm{~b}$ Impulse response to $1 \%$ increase in money growth: sticky wage with effort
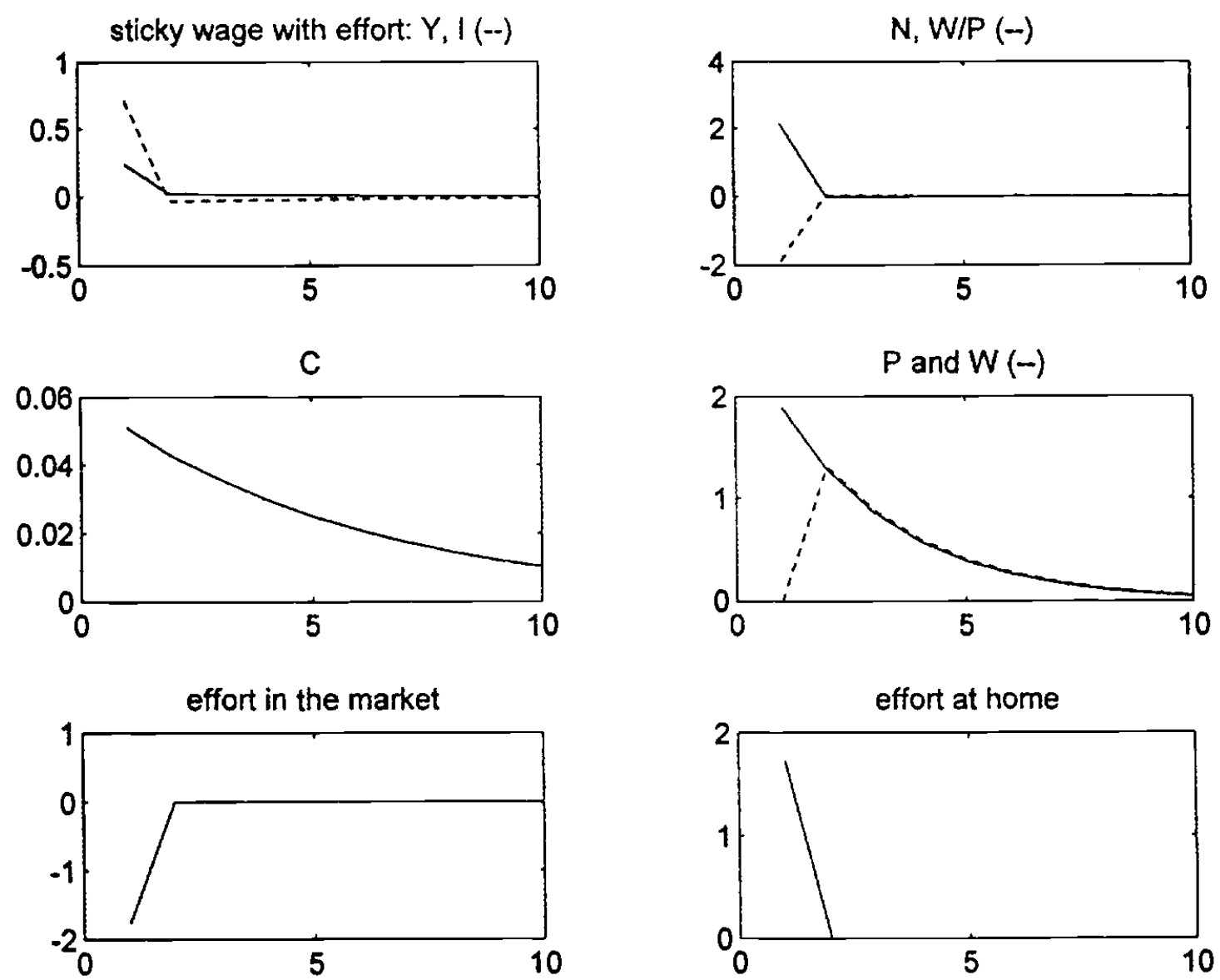